\title{
Importance of calibration for mathematical modeling of self-purification of lotic environments
}

\author{
Importância da calibração na modelagem matemática de autodepuração \\ em ambiente lótico
}

Marcio Ricardo Salla ${ }^{1 *}$, Lucianno Eduardo Fernandes ${ }^{1}$, Carlos Eugênio Pereira ${ }^{1}$, Hélio Correia da Silva Jhunior ${ }^{1}$ and Guilherme de Lima ${ }^{1}$

\begin{abstract}
${ }^{1}$ Programa de Pós-graduação em Engenharia Civil, Universidade Federal de Uberlândia - UFU, Av. João Naves de Ávila, 2121, Campus Santa Mônica, CEP 38400-902, Uberlândia, MG, Brazil *e-mail: marcio.salla@ufu.br
\end{abstract}

Cite as: Salla, M.R. et al. Importance of calibration for mathematical modeling of self-purification of lotic environments. Acta Limnologica Brasiliensia, 2016, vol. 28, e27.

Abstract: Aim: To demonstrate the importance of calibration in mathematical modeling of self-purification in lotic environments, this study simulated the behavior of various parameters in a river with average annual flows between 4.0 and $32.0 \mathrm{~m}^{3} \cdot \mathrm{s}^{-1}$, in a segment downstream from the entry of treated wastewater from a sewage treatment station (average monthly flow of $2.1 \mathrm{~m}^{3} \cdot \mathrm{s}^{-1}$ ). Methods: Numerical solution by finite difference of the advection-diffusion equation was used to study the dispersion and to quantify and monitor the evolution over time of the parameters DO, $\mathrm{BOD}_{5}, \mathrm{P}_{\text {total }}, \mathrm{NH}_{3}, \mathrm{NO}_{3}^{-}$and the levels of the heavy metals cadmium, chromium, copper, lead and zinc. The longitudinal behavior of the water quality parameters simulated by calibrating the state variables was compared with the behavior of the same parameters simulated via state variables available in the literature. The sensitivity of the state variables was also analyzed. Results: The calibration process led to good fits between the simulated and actual data for all the parameters analyzed. On the other hand, the comparison of the water quality model using calibrated state variables with the model based on state variables obtained in the literature revealed inconsistencies regarding the parameters $\mathrm{DO}, \mathrm{P}_{\text {total }}$, ammonia, nitrate and all the heavy metals. Conclusions: Considering the wide threshold ranges of the state variables in the literature and the dearth of studies on calibrating the coefficient of decay and quantifying the release of heavy metals by bottom sediment, this study can serve as a base for future investigations in lotic environments with similar hydraulic and water quality characteristics.

Keywords: River; Brazil; water quality; monitoring; model comparison.

Resumo: Objetivo: A fim de demonstrar a importância da calibração na modelagem matemática de autodepuração em ambiente lótico, este estudo simulou o comportamento de diversos parâmetros em um rio com vazóes médias anuais entre $4,0 \mathrm{a} 32,0 \mathrm{~m}^{3} \cdot \mathrm{s}^{-1}$, em um trecho a jusante do lançamento de efluente tratado por Estaçáo de Tratamento de Esgoto (vazão média mensal de $2,1 \mathrm{~m}^{3} \cdot \mathrm{s}^{-1}$ ). Métodos: a partir de solução numérica por diferença finita, foi utilizada a equação de difusão-advecçâo para estudar a dispersão, quantificação e acompanhamento da evolução ao longo do tempo dos parâmetros $\mathrm{OD}, \mathrm{DBO}_{5}, \mathrm{P}_{\text {total }}, \mathrm{NH}_{3}, \mathrm{NO}_{3}^{-}$e dos metais pesados cádmio, cromo, cobre, chumbo e zinco. $\mathrm{O}$ comportamento longitudinal dos parâmetros de qualidade da água simulados via calibração de variáveis de estado foi comparado com o comportamento dos mesmos parâmetros simulados via variáveis de estado da literatura. Também foi realizada uma análise de sensibilidade das variáveis de estado. Resultados: o processo de calibração permitiu bons ajustes entre dados simulados e medidos para todos os parâmetros analisados. Em contrapartida, a comparação da modelagem de qualidade da 
água a partir de variáveis de estado calibradas com a modelagem a partir de variáveis de estado obtidas na literatura trouxe inconsistências para os parâmetros $\mathrm{OD}, \mathrm{P}_{\text {total }}$, amônia, nitrato e todos os metais pesados. Conclusóes: levando-se em consideraçáo as amplas faixas limítrofes para as variáveis de estado na literatura e a carência de estudos sobre calibração do coeficiente de decaimento e a quantificação da liberaçáo pelo sedimento de fundo de metais pesados, este estudo pode embasar futuros trabalhos em ambiente lótico com características hidráulicas e de qualidade da água similares.

Palavras-chave: Rio; Brasil; qualidade da água; monitoramento; comparação de modelos.

\section{Introduction}

Socioeconomic development and demographic growth are accompanied by increased demand for water with good quality. Indeed, clean water is a vital resource for the health and development of any community (Bueno et al., 2005).

Multiple uses of surface water and uncontrolled discharge of sanitary wastes cause negative impacts on the quantity and quality of water in urbanized regions (Zhang et al., 2011; McKnight et al., 2012; Sulis \& Sechi, 2013; Yenilmez \& Aksoy, 2013; Salla et al., 2013a). Among the anthropic actions that affect water bodies, release of inorganic and carbonaceous and nitrogenous organic compounds particularly degrades water quality, since the water has limited capacity for biochemical degradation of supernatant organic matter, so that the dissolved oxygen, among its various functions, is a determining factor for the survival of living organisms in the water. Heavy metals also pose a severe risk of immediate and future damages. These come from varied sources, ranging from natural erosion processes to industrial or mining wastes and pesticides in runoff water from farms. Unlike biodegradable organic compounds, heavy metals are recalcitrant and can accumulate in environmental components and aquatic organisms, causing toxic reactions (Baird, 2002).

Mathematical modeling of water quality in lotic environments is a fundamental tool for planning use and managing water resources on the watershed scale. Many models are available in the literature and the mathematical interpretation of the phenomena and parameters modeled can assume diverse forms and involve varied hypotheses. Therefore, the model needs to be chosen in view of the objectives and variables of interest (Salla et al., 2015).

Regarding the mathematical interpretation of environmental phenomena in lotic environments, the information in the literature on biochemical reaction coefficients, sediment removal coefficients, benthic demands and resurgence is ample. These aspects depend on the hydraulic characteristics of the channel, the prior water quality and the quality of the incoming effluent, among others. Wide variations are presented for various coefficients and demands, which can cause the results obtained by mathematical simulation of water quality to deviate markedly from the real situation (Salla et al., 2014b). With respect to heavy metals, the leading models at present contain mathematical equations reflecting the behavior of metals (often identified under the umbrella term toxic contaminants), but lack threshold indicators of the coefficients included in these models. In other words, they lack support from studies of water courses (be they small, medium or large) for calibration of the coefficients related to the behavior of heavy metals.

In general, mathematical modeling satisfactorily reflects the self-purification process when the coefficients, benthic demands and resurgence features are calibrated based on water quality data monitored along the water course (Salla et al., 2015). Also, the determination in laboratory scale of the benthic demand for dissolved oxygen (DO) is beneficial in mathematical modeling because it reduces the variables to be calibrated, due to the high sensitivity of this factor in the behavior of the parameters DO and biochemical oxygen demand (BOD).

In this context, by using six monitoring points along the Uberabinha River, located in the "Triângulo Mineiro" region of the state of Minas Gerais, Brazil, as the basis for comparison, it was possible to show the importance of calibration in the mathematical modeling of self-purification in a lotic environment, by evaluating the behavior of the longitudinal profiles of the parameters $\mathrm{DO}$, BOD, ammoniac nitrogen $\left(\mathrm{NH}_{3}\right)$, nitrate $\left(\mathrm{NO}_{3}{ }^{-}\right)$, total phosphorus $\left(\mathrm{P}_{\text {total }}\right)$ and the metals cadmium $(\mathrm{Cd})$, chromium $(\mathrm{Cr})$, copper $(\mathrm{Cu})$, lead $(\mathrm{Pb})$ and zinc ( $\mathrm{Zn})$.

\section{Materials and Methods}

\subsection{Study area}

The Uberabinha River watershed is located in the western part of the state of Minas Gerais, between the coordinates $18^{\circ} 42^{\prime}$ and $18^{\circ} 54^{\prime}$ south latitude 
and $48^{\circ} 18^{\prime}$ and $48^{\circ} 30^{\prime}$ west longitude (Figure 1 ). The river's headwater is located in the municipality of Uberaba, from where it runs about $140 \mathrm{~km}$ until emptying into the Araguari River. The river basin covers an area of approximately 22 thousand $\mathrm{km}^{2}$, with altitude between 550 and $1000 \mathrm{~m}$ and rainfall of $1,505 \mathrm{~mm}$ in 2015 . The climate in the region is tropical, with a dry season from May to October and wet season from November to April.

The basin is divided into three distinct regions, the upper, middle and lower (see Figure 1). The upper region is located in the northern part of the municipality of Uberlândia and southern part of Uberaba, in an area of sedimentary tableland, containing expansive moist systems in open environments, in the form of natural corridors or fields, at altitudes ranging between 900 and $1000 \mathrm{~m}$, configuring natural water reservoirs that assure perennial drainage. The middle region has areas of moderately dissected topography and vegetation mainly consisting of small patches of riparian forest and fragments of savanna and cerradão (woodland with a well-developed arboreal canopy), covering most of Uberlândia. The lower region has intensely dissected topography in the lower portion of the basin (downstream from Uberlândia), and the vegetation is characterized by seasonal forest fragments and cerradão, at altitudes varying from 640 to 800 m, where the Uberabinha River empties into the Araguari River (Schneider, 1996).

The population in Uberlândia city is about 650 thousand inhabitants. Uberlândia has three waste treatment stations (WTEs), but $95 \%$ of the sewage load is treated by the Uberabinha WTE, which discharges the treated effluent into the river's lower course (Salla et al., 2014b).

The main uses of the water from the Uberabinha River are human and livestock consumption, irrigation (sugarcane, soybeans and corn), food processing factories and energy generation (Rosolen et al., 2009). The demands from surface and underground water in the basin for human and animal consumption, irrigation and industry in 2015 were 17.07 and $1.61 \mathrm{hm}^{3}$. month $^{-1}$, respectively. Of the total surface demand, $14.77 \mathrm{hm}^{3} \cdot$ month $^{-1}$ is allocated for human consumption, of which $9.59 \mathrm{hm}^{3} \cdot$ month $^{-1}$ is taken from the Uberabinha River and $5.18 \mathrm{hm}^{3}$. month ${ }^{-1}$ from Bom Jardim Stream.

The river basin has two small run-of-the-river (ROR) hydroelectric plants downstream from the discharge point of the Uberabinha WTS, in the

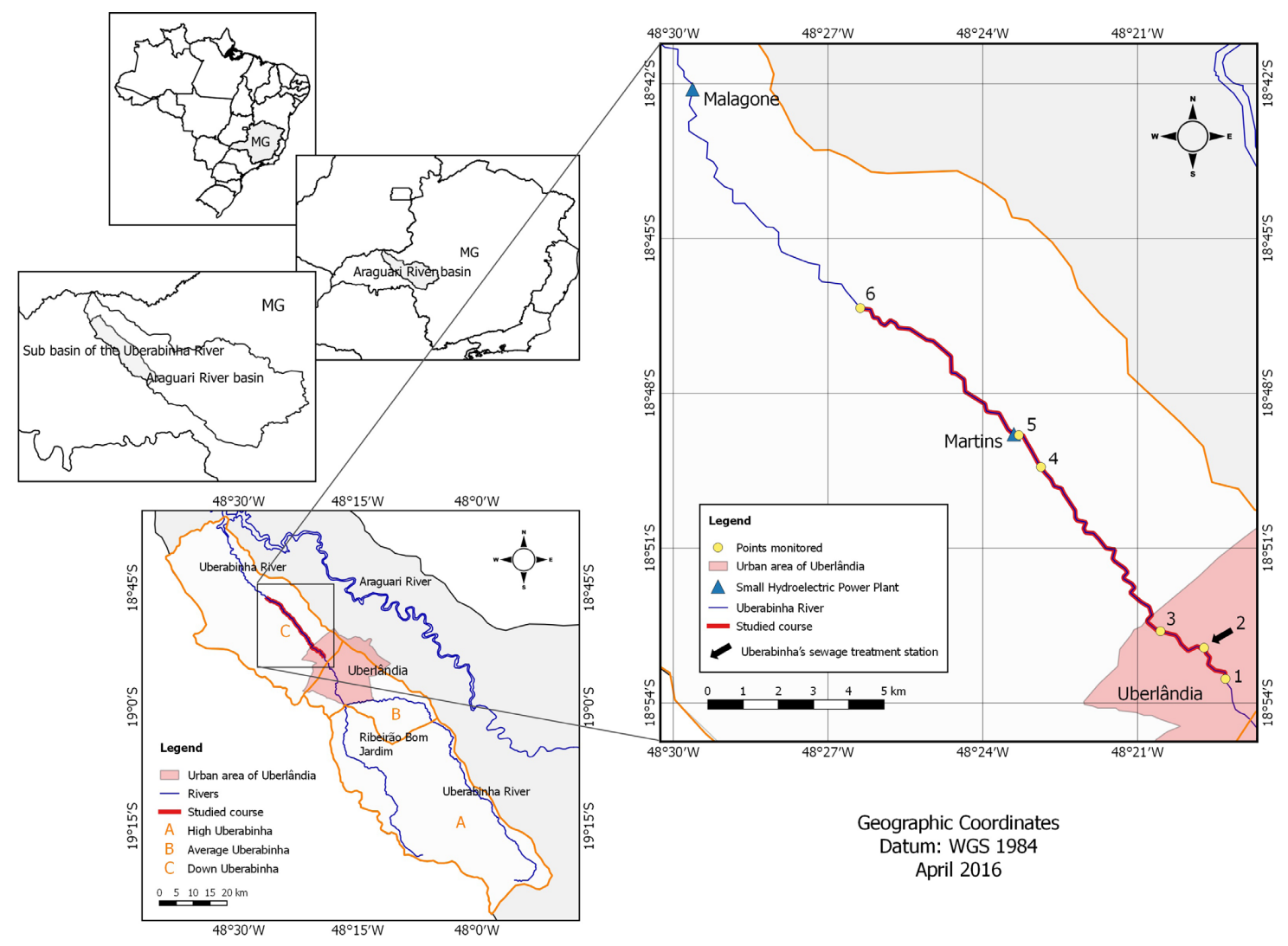

Figure 1. Uberabinha River watershed and monitoring points. 
river's lower course (Martins and Malagone power plants, in sequence), as depicted in Figure 1.

We selected five monitoring points along the lower course of the Uberabinha River (points 1, 3, 4, 5 and 6) and one point at the outlet of Uberabinha WTS, before confluence with the river (point 2). The segment studied has length of about $19 \mathrm{~km}$, from just upstream from the confluence of the river and the effluent from Uberabinha WTS (identified by point 1 - Figure 1) until the environs of the Martinésia district (identified by point 6 - Figure 1).

\subsection{Input data}

\subsubsection{Water quality}

Samples for analysis of water quality were obtained from all points (1 to 6), in the dry season from June to October 2015, to calibrate the coefficients of the physico-chemical reactions, benthic demands, resurgence and diffuse loads belonging to the mathematical equations formulated to represent the self-purification process in this part of the river. The parameters monitored were DO, $\mathrm{BOD}, \mathrm{NH}_{3}, \mathrm{NO}_{3}^{-}, \mathrm{P}_{\text {total }}$ and the heavy metals $\mathrm{Cd}$, $\mathrm{Cr}, \mathrm{Cu}, \mathrm{Pb}$ and $\mathrm{Zn}$. The techniques for preservation, sampling and laboratory analysis followed the recommendations of the ABNT NBR 9898:1987 (ABNT, 1987).

\subsubsection{River flow}

The flow of the Uberabinha River was measured only at points 1 and 6 , in the dry season from June to October 2015. These points correspond to the start and end of the segment studied. Because of the existence of the Martins ROR power plant near point 5 , the flow monitoring at points 1 and 6 was used to calculate the water balance, where:

- in the stretch between point 1 and Martins PP, we estimated the fixed flow as being equal to the sum of the river at point 1 and the effluent from Uberabinha WTS (this was possible because few streams exist along this segment of the river, so their contribution could be considered negligible); and

- in the stretch between Martins PP and point 6 , we estimated the fixed flow to be equal to that obtained at point 6 (again possible due to the existence of few streams).

To measure the flow speed, we used an acoustic Doppler current profiler (ADCP) coupled to an echobathymeter calibrated for the river channel cross section. Then a continuity equation was used in the RiverSurveyor computational tool to determine the water speed.

\subsubsection{Flow at Uberabinha WTS}

The flow at the outlet of Uberabinha WTS, during the dry season from June to October 2015, measured at point 2 (Figure 1), was estimated according to Salla et al. (2013b). The flow was obtained by the flow equation for water consumption distribution multiplied by the coefficient of return, which according to ABNT NBR 9649:1986 (ABNT, 1986) and 14486:2000 (ABNT, 2000) is set at 0.80 when no local empirical data are available.

\subsection{Mathematical modeling of the physical and biochemical processes}

To study the dispersion and quantify and accompany the evolution over time of the pollutants discharged into the river, we used the advection-diffusion equation, represented in (1).

$\frac{\partial \overline{\mathrm{C}}}{\partial \mathrm{t}}+\overline{\mathrm{u}_{\mathrm{i}}} \cdot \frac{\partial \overline{\mathrm{C}}}{\partial \mathrm{x}_{\mathrm{i}}}=\frac{\partial}{\partial \mathrm{x}_{\mathrm{i}}}\left(\right.$ Dt. $\left.\frac{\partial \overline{\mathrm{C}}}{\partial \mathrm{x}_{\mathrm{i}}}\right) \pm \mathrm{g}$

In Equation 1: $\partial \overline{\mathrm{C}} / \partial \mathrm{t}$ demotes the variation of concentration in time; $\bar{u}_{i} . \partial \overline{\mathrm{C}} / \partial \mathrm{x}_{\mathrm{i}}$ represents the pollutant transport by advection; $\partial / \partial \mathrm{x}_{\mathrm{i}}\left(\right.$ Dt. $\left.\partial \mathrm{C} / \partial \mathrm{x}_{\mathrm{i}}\right)$ represents the pollutant transport by turbulent diffusion; $g$ is the source or sink term (conversions or physical and biochemical processes undergone by the water quality parameter); and $i$ represents the directions $\mathrm{x}, \mathrm{y}$ and $\mathrm{z}$.

Chapra (1997) suggests the following simplifications of Equation 1 for water quality modeling in lotic environments: permanent flow $(\partial \overline{\mathrm{C}} / \partial \mathrm{t}$ equal to zero); unidirectional flow (only longitudinal direction $x$ ) on a monthly scale; and negligible turbulent diffusion term. The reasons are: concentration of the pollutant in domestic effluent have little variation throughout the day, which suggests a concentration fixed or permanent over month; most mathematical modeling of self-purification of lotic environment consider a complete and instant mixing of river main and tributary pollution load, or despises the mixing zone (pollutant plume). From the complete mixture, the sidewalls and bottom of the channel act as barrier that prevents the dispersion of the pollutant in $y$ and $\mathrm{z}$ directions, enabling the rejection of modeling in $\mathrm{y}$ and $\mathrm{z}$ directions; in lotic ambient the advective effect prevails over the diffusive effect in behavior of different pollutants, allowing despise the diffusive 
effect. The opposite occurs in lentic environment (storage reservoirs).

With these simplifications, Equation 1 becomes Equation 2.

In Equation 2, $\overline{\mathrm{u}} / \partial \mathrm{x}$ is represented by $1 / \partial \mathrm{t}$, and numerical solution by finite difference results in Equation 3.

$\overline{\mathrm{u}} \cdot \frac{\partial \overline{\mathrm{C}}}{\partial \mathrm{x}}= \pm \mathrm{g}$

$C_{n+1}=C_{n} \pm g \cdot\left(t_{n+1}-t_{n}\right)$

In Equation 2, $\overline{\mathrm{u}}$ is the average velocity. In Equation 3: $C_{n+1}$ represents the concentration of the parameter in the river at time $t_{n+1}$ after the start of the modeling and $C_{n}$ represents the concentration of the parameter in the river at time $t_{n}$ after the start of the modeling.

The term $g$ for the parameters $\mathrm{DO}, \mathrm{BOD}, \mathrm{NH}_{3}$, $\mathrm{NO}_{3}-\mathrm{P}_{\text {total }}, \mathrm{Cd}, \mathrm{Cr}, \mathrm{Cu}, \mathrm{Pb}$ and $\mathrm{Zn}$ is represented by Equations 4, 5, 6, 7, 8 and 9. We used a spreadsheet program for mathematical solution of these equations, with spatial discretization of $100 \mathrm{~m}$.

$$
\begin{aligned}
& g(D O)=+k_{a} \cdot 1.024^{(T-20)} \cdot\left(D_{\text {sat }}-D O\right)- \\
& \mathrm{k}_{\mathrm{d}} \cdot 1.047^{(\mathrm{T}-20)} \cdot \mathrm{BOD}-\mathrm{R}_{\mathrm{O} 2-\text { ammonia }} \cdot f_{\text {nitr }} \cdot \mathrm{k}_{\mathrm{an}} \cdot 1.080^{(\mathrm{T}-20)} \cdot \mathrm{NH}_{3}- \\
& \mathrm{R}_{\mathrm{O} 2-\text { nitrito }} \cdot \mathrm{f}_{\text {nitr }} \cdot \mathrm{k}_{\mathrm{nn}} \cdot 1.047^{(\mathrm{T}-20)} \cdot \mathrm{NO}_{2}{ }^{-}-\mathrm{S}_{\mathrm{d}} \cdot \mathrm{h}^{-1} \\
& \mathrm{~g}(\mathrm{BOD})=-\mathrm{k}_{\mathrm{d}} \cdot 1.047^{(\mathrm{T}-20)} \cdot \mathrm{BOD}- \\
& \mathrm{k}_{\mathrm{s}} \cdot 1.024^{(\mathrm{T}-20)} \cdot \mathrm{BOD}+\mathrm{L}_{\text {diffus }} \\
& \mathrm{g}(\mathrm{NH} 3)=+\mathrm{k}_{\mathrm{oa}} \cdot 1,047^{(\mathrm{T}-20)} \cdot \mathrm{N}_{\mathrm{org}}{ }^{-} \\
& \mathrm{R}_{\mathrm{O} 2-\mathrm{ammonia}} \cdot \mathrm{f}_{\text {nitr }} \cdot \mathrm{k}_{\mathrm{an}} \cdot 1 \cdot 080^{(\mathrm{T}-20)} \cdot \mathrm{NH}_{3} \\
& \mathrm{~g}\left(\mathrm{NO}_{3}-\right)=+\mathrm{R}_{\mathrm{O} 2-\text { nitrite }} \cdot \mathrm{f}_{\text {nitr }} \cdot \mathrm{k}_{\mathrm{nn}} \cdot 1 \cdot 047^{(\mathrm{T}-20)} \cdot \mathrm{NO}_{2}{ }^{-} \\
& \mathrm{g}(\mathrm{Ptotal})=-\mathrm{kP} \cdot \mathrm{P}_{\text {total }}+\mathrm{SP}_{\mathrm{P}} \\
& \mathrm{g}(\text { metal })=-\mathrm{k}_{\text {metal }} \cdot C_{\text {metal }}+S_{\text {metal }}
\end{aligned}
$$

Where: $T$ is water temperature, in ${ }^{\circ} \mathrm{C} ; D O_{\text {sat }}$ is dissolved oxygen saturation, in mg. $\mathrm{L}^{-1} ; D O$ is dissolved oxygen, in mg. $\mathrm{L}^{-1} ; k_{a}$ is the coefficient of reaeration, in day ${ }^{-1} ; B O D$ is the biochemical oxygen demand, in mg. $\mathrm{L}^{-1} ; k_{d}$ is the coefficient of carbonaceous organic matter decomposition, in day $^{-1} ; L_{\text {diffus }}$ is the diffuse BOD load, in g. $\mathrm{m}^{-3}$. day $^{-1}$; $S_{d}$ is the benthic DO demand, in $\mathrm{gO}_{2} \cdot \mathrm{m}^{-2}$. day ${ }^{-1}$; $h$ is the water depth, in $\mathrm{m}$; $k_{s}$ is the coefficient of decay by sedimentation of carbonaceous organic matter, in day ${ }^{-1} \mathrm{NH}_{3}$ is ammoniac nitrogen, in mg. $\mathrm{L}^{-1} ; N_{\text {org. }}$ is organic nitrogen, in mg. $\mathrm{L}^{-1} ; \mathrm{NO}_{2}^{-}$is nitrite, in mg. $\mathrm{L}^{-1} ; \mathrm{NO}_{3}^{-}$is nitrate, in mg. $\mathrm{L}^{-1} ; k_{n n}$ is the coefficient of conversion of $\mathrm{NO}_{2}^{-}$into $\mathrm{NO}_{3}^{-}$, in day ${ }^{-1}$; $k_{o a}$ is the coefficient de conversion of $\mathrm{N}_{\text {org }}$ into $\mathrm{NH}_{3}$, in day ${ }^{-1} ; R_{\text {O2-ammonia }}$ is the oxygen consumption by oxidation of $\mathrm{NH}_{3}$, in $\mathrm{mgO}_{2 \text { cons }} \cdot \mathrm{mgNH}_{3 \text { oxid }}{ }^{-1} ; R_{\text {O2-nitrite }}$ is the oxygen consumption for oxidation of $\mathrm{NO}_{2}^{-}$, in $\mathrm{mgO}_{2 \text { cons }} \cdot \mathrm{mgNO}_{2 \text { oxid }}^{-} ; f_{\text {nitr }}$ is the nitrification factor, non-dimensional; $K_{a n}$ is the coefficient of conversion of $\mathrm{NH}_{3}$ into $\mathrm{NO}_{2}^{-}$, in day ${ }^{-1} P_{\text {total }}$ is the total phosphorus, in mg. $\mathrm{L}^{-1} ; k_{P}$ is the coefficient of decay of $P_{\text {total }}$ in day ${ }^{-1} ; S_{P}$ is the release of de $\mathrm{P}_{\text {inorg }}$ by the bottom sediment, in $\mathrm{g} \cdot \mathrm{m}^{-3} \cdot \mathrm{day}^{-1} ; C_{\text {metal }}$ is the total metals (cadmium, copper, chromium, lead and zinc), in mg. $\mathrm{L}^{-1} ; k_{\text {metal }}$ is the coefficient of decay of metals, in day ${ }^{-1}$; and $S_{\text {metal }}$ is the release of metals by the bottom sediment, in g. $\mathrm{m}^{-3}$. day ${ }^{-1}$.

In this study we only analyzed the decay of total phosphorus, whose coefficient of decay was identified by $k_{P}\left(\right.$ day $\left.^{-1}\right)$. Therefore, this coefficient encompasses the coefficient of conversion of organic into inorganic phosphorus $k_{o i}\left(\mathrm{day}^{-1}\right)$ and the coefficient of sedimentation of inorganic phosphorus $k_{s p o}\left(\right.$ day $\left.^{-1}\right)$.

The physical and biochemical processes to which the water quality parameters are subject, along with the interaction of the parameters, are presented in Figure 2 for better understanding of the behavior of the water course.

\subsection{State variables from the literature}

In modeling the longitudinal behavior of the water quality parameters from the state variables available in the literature, we used the averages for $k_{s,} k_{o a,} K_{a n}$ and $k_{p}$, from data for all months. For the coefficient of metal decay $k_{\text {metal }}$, we also employed a fixed value for all months, equal to 0.01 day $^{-1}$, which is the standard value supplied by the Aqua Tool computational tool. This tool, used to support water resource planning decisions, recently incorporated the option of modeling various toxic contaminants in its water quality modeling module (GESCAL module), such as heavy metals, emerging organic contaminants and detergents, among others (Salla et al., 2014b; Paredes-Arquiola et al., 2010).

The coefficients $k_{a}$ and $k_{d}$ were estimated by equations from the literature, which depend on water level and average runoff and flow speed (see Table 1), so they varied over the months. The hydraulic ratios were obtained from Manning's equation, assuming:

- The entire $19 \mathrm{~km}$ segment of the Uberabinha River has uniform trapezoidal cross section, with channel base width $b$ ranging from 23 and $27 \mathrm{~m}$ and slope of the river banks set at $45^{\circ}$. For this, we performed bathymetric field measurements in October 2015 at the end points of the river segment studied 


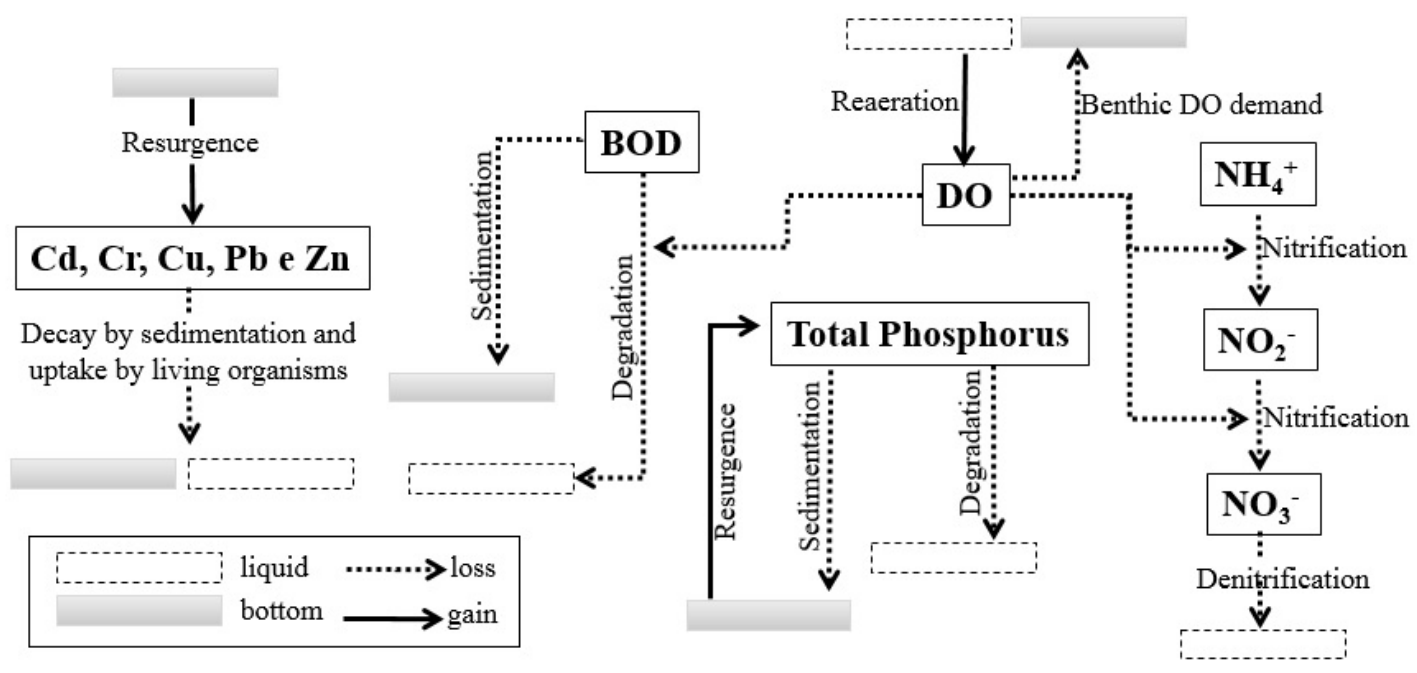

Figure 2. Physical and biochemical processes and interactions of the parameters.

Table 1. Empirical equations to estimate $k_{a}$ and $k_{d}$ (base $e, 20^{\circ} \mathrm{C}$ ) and increment of DO in cascade.

\begin{tabular}{|c|c|c|c|}
\hline Coeff. & Empirical equation & Range of application & Authors \\
\hline \multirow{6}{*}{$\begin{array}{c}k_{a} \\
\left(\text { day }^{-1}\right)\end{array}$} & \multirow{2}{*}{$\begin{array}{l}3.73 \cdot v^{0.5} \cdot h^{-1,5} \\
\text { (in river segment) }\end{array}$} & $0.6 \leq h<4.0 \mathrm{~m}$ & \multirow{2}{*}{$\begin{array}{l}\text { O'Connor \& Dobbins (1985), cited in } \\
\text { Von Sperling (2007) }\end{array}$} \\
\hline & & $0.05 \leq v<0.8 \mathrm{~m} . \mathrm{s}^{-1}$ & \\
\hline & \multirow{2}{*}{$\begin{array}{c}5.0 \cdot v^{0.97} \cdot h^{-1.67} \\
\text { (in river segment) }\end{array}$} & $0.6 \leq h<4.0 \mathrm{~m}$ & \multirow{2}{*}{$\begin{array}{l}\text { Churchill (1962), cited in Von Sperling } \\
\text { (2007) }\end{array}$} \\
\hline & & $0.8 \leq v<1.5 \mathrm{~m} . \mathrm{s}^{-1}$ & \\
\hline & \multirow{2}{*}{$\begin{array}{l}5.3 . v^{0.67} \cdot h^{-1.85} \\
\text { (in river segment) }\end{array}$} & $0.1 \leq h<0.6 \mathrm{~m}$ & \multirow{2}{*}{$\begin{array}{l}\text { Owens (1976), cited in Von Sperling } \\
(2007)\end{array}$} \\
\hline & & $0.05 \leq v<1.5{\mathrm{~m} . \mathrm{s}^{-1}}^{-1}$ & \\
\hline \multirow{3}{*}{$\begin{array}{c}k_{d} \\
\left(\text { day }^{-1}\right)\end{array}$} & $0.3^{*}\left(h^{*} 2.5^{-1}\right)^{-0.434}$ & $h \leq 2.5 \mathrm{~m}$ & \multirow{3}{*}{ Von Sperling (2007) } \\
\hline & 0.3 & $h>2.5 \mathrm{~m}$ & \\
\hline & $1.8^{*} Q^{-0.49}$ & $\begin{array}{c}0.3<h<10 \mathrm{~m} \\
0.15<Q<250 \mathrm{~m}^{3} . \mathrm{s}^{-1}\end{array}$ & \\
\hline $\begin{array}{l}\text { Increment of DO } \\
\text { in cascade }\end{array}$ & $\begin{array}{l}C_{e}=C_{o}+k \cdot\left(C_{s}-C_{d}\right) \\
k=1-1.09 \cdot h^{\star-0.128}\end{array}$ & $h^{*}>4.0 \mathrm{~m}$ & Von Sperling (2007) \\
\hline
\end{tabular}

$v$ is the average water velocity $\left(\mathrm{m} . \mathrm{s}^{-1}\right) ; h$ is the water depth $(\mathrm{m}) ; b^{*}$ is the difference between the water levels upstream and downstream from the power plant; $C_{e}$ is the DO concentration downstream from the power plant; $C_{o}$ is the $\mathrm{DO}$ concentration upstream from the power plant; $k$ is the coefficient of efficiency (-); and $C_{s}$ is the DO saturation concentration.

(points 1 and 6 - Figure 1), using the echobathymeter connected to the ADCP;

- The base material in the channel is composed of basalt and a few small boulders $\left(\eta_{1}\right.$ equal to $0.035 \mathrm{~m}^{-1 / 3} . \mathrm{s}$, according to Chow, 2009) and the banks are covered with mediums-size plant species $\left(\eta_{2}\right.$ equal to $0.065 \mathrm{~m}^{-1 / 3} . \mathrm{s}$, according to Chow, 2009). By the method of Cowan, we used a roughness coefficient of $0.046 \mathrm{~m}^{-1 / 3} \cdot \mathrm{s}$, assumed to be fixed along the entire river segment. Among the various methods to estimate Manning's roughness coefficient, the method of Cowan is widely used because it considers various factors that influence the flow resistance (Chow, 2009);
- The longitudinal declivity of the channel bottom was obtained from elevation data measured by radar interferometry from the TOPODATA database (INPE, 2015) in the QGIS tool, with horizontal sampling interval of $30 \mathrm{~m}$, subsequently generalized to $100 \mathrm{~m}$. Methods that use GIS are nearer to reality than other less precise methods, such as average declivity in the entire river stretch computed by the starting and ending elevations obtained in the Google Earth tool.

In these simulations, because of the relative scarcity of data in the literature and the fact we only took measurements in the dry season, the resurgence loads $S_{P}$ and $S_{\text {metal }}$, the benthic DO demand $S_{d}$ and

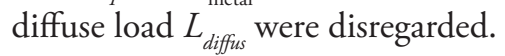


2.5. Calibration and sensitivity analysis of the coefficients of biochemical, diffusion and resurgence loads

Based on numerical solution by finite difference of the differential Equations 4 to 9, with a discretization step of $100 \mathrm{~m}$, we simulated the profile of each parameter. We then compared these simulated profiles with the values measured at points 3, 4, 5 and 6 and then performed an adjustment so that the simulated values were as close as possible to the empirical values. That adjustment involved calibration of the following state variables: coefficients of biochemical reactions $k_{a^{\prime}}, k_{d^{\prime}} k_{s,} k_{o a_{0}} k_{a n}$ $k_{n n}, k_{p}, k_{\text {metal }} ;$ diffuse load $L_{\text {diffus }}$; and resurgence loads $S_{\text {metal }}$ and $S_{p}$. The benthic demand $S_{d}$ was measured in the laboratory by the method described next.

The process involved trial and error, starting by attributing average values from the literature as the initial calibration step, attributing fixed values in a stretch with the same longitudinal declivity. We identified five stretches along the portion of the Uberabinha River studied, with the separation criterion being proximity of longitudinal declivity. Figure 3 identifies the river stretches and monitoring points.

The sharpest changes in longitudinal declivity occur in stretches 1 and 3 . In stretch 1 the declivity is $3.67 \%$, while in stretch 3 it is $6.09 \%$ due to the existence of the Martins power plant. Stretches 2 and 5 have the smallest longitudinal declivities, equal to $0.47 \%$ and $0.29 \%$, respectively. Stretch 4 has intermediate declivity of $0.79 \%$.

The number of state variables calibrated in this study is large. Sensitivity analysis of the coefficients, the resurgence loads and benthic DO demand allow assessing the relative importance of each state variable in the behavior of the various water quality parameters. The interactions of these parameters are illustrated in Figure 2. In each river stretch we quantified the average percentage variation of the diverse parameters based on oscillation by $+10 \%$ and $-10 \%$ of all the coefficients, resurgence loads and benthic $\mathrm{BO}$ demand. In each simulation, while one variable fluctuated $+10 \%$ or $-10 \%$, the others were held steady at the original calibrated value.

\subsection{Quantification of the benthic DO demand}

Quantification of the benthic BO demand $\left(S_{d}\right)$ was necessary to reduce the number of coefficients to be calibrated, since this term is highly sensitive in the behavior of the parameters DO and BOD (Salla et al., 2014b). The benthic DO demand $S_{d}$ (in $\mathrm{gO}_{2} \cdot \mathrm{m}^{-2}$. day ${ }^{-1}$ ) was quantified at five points (points 1,3, 4, 5 and 6), by collecting a water sample from just above the river bed. In the laboratory, the samples were stored in the bottles of an OxiTop ${ }^{\circledR}$ IS 6 system under controlled temperature conditions $\left(20^{\circ} \mathrm{C}\right)$. With the daily values of $\mathrm{DO}$ consumption inside each bottle and considering the internal cross section as the surface area, it was possible to estimate the benthic DO demand by applying Equation 10 .

$S_{d}=\left[\left(B D_{0}-B^{B O D}\right) \cdot 10^{-3} \cdot A^{-1}\right]$

Where: $S_{d}$ is the benthic DO demand $\left(\mathrm{gO}_{2} \cdot \mathrm{m}^{-2}\right.$. day $\left.^{-1}\right) ; B O D_{0}$ is the remaining $\mathrm{BOD}$ at time zero (mg.L.-1); $B O D_{1}$ is the remaining BOD at the end of the first day $\left(\mathrm{mg} . \mathrm{L}^{-1}\right)$; and $A$ is the internal bottle cross section area $\left(\mathrm{m}^{2}\right)$, set at $0.00442 \mathrm{~m}^{2}$.

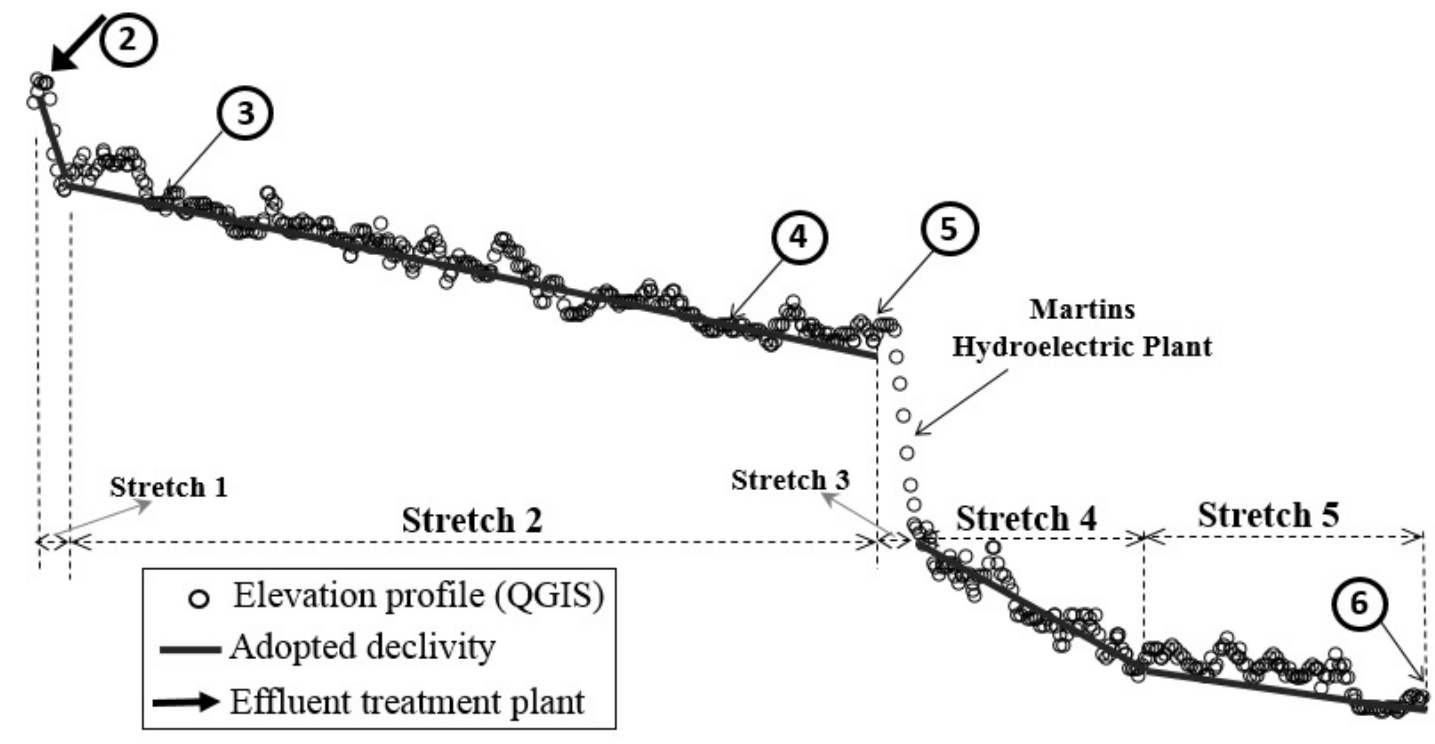

Figure 3. Identification of stretches and monitoring points. 
The samples were collected at the interface between the liquid portion and the river bottom using a bottom collector, which allowed obtaining a sample from the water-solid interface without loss or contamination of the sample while bringing it to the surface.

\subsection{Comparison of the water quality model with calibrated state variables and those obtained in the literature}

Because of the scarcity of historical water quality data in Brazil, many studies of self-purification in lotic environments estimate the state variables based on fixed values and empirical equations from the literature, related to the morphological and hydraulic characteristics of the channel, previous river water quality and quality of the effluent released. However, according to Salla et al. (2014a), mathematical modeling satisfactorily reflects the self-purification process when these variables are calibrated against water quality data from monitoring the stretch of the river of interest.

To demonstrate the importance of calibration in the mathematical modeling of self-purification, we compared the longitudinal behavior of the water quality parameters studied here after calibration/measurement of the state variables with the longitudinal behavior of the same parameters obtained from state variables in the literature

\section{Results and Discussion}

\subsection{Input data}

The flow and water quality data obtained by monitoring are reported in Table 2. The water quality data from points 1 and 2 and the flow from points 1 and 6 were used as input for the simulations, while the water quality data from points 3 to 6 were employed in calibrating the state variables.

The focus of this study is evaluation of the importance of calibrating a water quality model in a lotic environment in the dry season. According to data from the National Meteorology Institute (INMET, 2016), collected at the Uberlândia Automatic Surface Weather Observation Station, the cumulative monthly rainfall figures in 2015 were $25.4 \mathrm{~mm}$ in June, $8.2 \mathrm{~mm}$ in July, zero in August, $46.2 \mathrm{~mm}$ in September and $86.0 \mathrm{~mm}$ in October.

The field work was performed in days without rain from June to September 2015. In October 2015, the weather station on the collection day indicated the occurrence of precipitation, without

Table 2. Flow and water quality data at six monitoring points.

\begin{tabular}{|c|c|c|c|c|c|c|}
\hline Parameter & Point 1 & Point 2 & Point 3 & Point 4 & Point 5 & Point 6 \\
\hline $\begin{array}{l}\text { Flow } \\
\left(\mathrm{m}^{3} \cdot \mathrm{s}^{-1}\right)\end{array}$ & $\begin{array}{l}4.2-8.0 \\
5.9 \pm 1.5\end{array}$ & $\begin{array}{l}2.0-2.2 \\
2.1 \pm 0.1\end{array}$ & - & - & - & $\begin{array}{l}4.8-9.1 \\
6.1 \pm 1.8\end{array}$ \\
\hline $\begin{array}{c}\mathrm{DO} \\
\left(\mathrm{mg} \cdot \mathrm{L}^{-1}\right)\end{array}$ & $\begin{array}{l}3.3-6.2 \\
4.9 \pm 1.3\end{array}$ & $\begin{array}{l}0.0-0.0 \\
0.0 \pm 0.0\end{array}$ & $\begin{array}{l}1.5-5.2 \\
3.5 \pm 1.5\end{array}$ & $\begin{array}{l}1.2-3.4 \\
2.3 \pm 1.0\end{array}$ & $\begin{array}{l}0.7-2.7 \\
1.9 \pm 0.8\end{array}$ & $\begin{array}{l}2.4-7.1 \\
4.8 \pm 1.8\end{array}$ \\
\hline $\begin{array}{l}\mathrm{BOD}_{5,20} \\
\left(\mathrm{mg}^{5-1}\right)\end{array}$ & $\begin{array}{c}3.0-34.0 \\
12.2 \pm 12.8\end{array}$ & $\begin{array}{c}98.0-174.0 \\
124.2 \pm 29.6\end{array}$ & $\begin{array}{l}25.0-95.0 \\
44.0 \pm 28.9\end{array}$ & $\begin{array}{c}9.0-125.0 \\
45.2 \pm 45.7\end{array}$ & $\begin{array}{c}7.0-138.0 \\
47.4 \pm 51.8\end{array}$ & $\begin{array}{c}6.0-137.0 \\
46.8 \pm 51.6\end{array}$ \\
\hline$\underset{\left(m g \cdot L^{-1}\right)}{N_{\text {org }}}$ & $\begin{array}{l}0.20-0.30 \\
0.25 \pm 0.04\end{array}$ & $\begin{array}{l}19.0-20.0 \\
19.5 \pm 0.5\end{array}$ & - & - & - & - \\
\hline $\begin{array}{c}\mathrm{NH}_{3} \\
\left(\mathrm{mg} \cdot \mathrm{L}^{-1}\right)\end{array}$ & $\begin{array}{l}0.02-0.40 \\
0.08 \pm 0.05\end{array}$ & $\begin{array}{l}0.08-0.20 \\
0.12 \pm 0.05\end{array}$ & $\begin{array}{l}0.03-0.14 \\
0.08 \pm 0.05\end{array}$ & $\begin{array}{l}0.03-0.14 \\
0.08 \pm 0.05\end{array}$ & $\begin{array}{l}0.03-0.13 \\
0.08 \pm 0.05\end{array}$ & $\begin{array}{l}0.03-0.14 \\
0.07 \pm 0.05\end{array}$ \\
\hline $\begin{array}{c}\mathrm{NO}_{2}^{-} \\
\left(\mathrm{mg}^{-} \mathrm{L}^{-1}\right)\end{array}$ & $\begin{array}{l}0.44-1.26 \\
0.86 \pm 0.34\end{array}$ & $\begin{array}{l}0.02-0.75 \\
0.46 \pm 0.27\end{array}$ & $\begin{array}{l}0.41-1.19 \\
0.86 \pm 0.29\end{array}$ & $\begin{array}{l}0.06-0.35 \\
0.22 \pm 0.12\end{array}$ & $\begin{array}{l}0.03-0.23 \\
0.10 \pm 0.08\end{array}$ & $\begin{array}{l}0.75-2.74 \\
1.78 \pm 0.72\end{array}$ \\
\hline $\begin{array}{c}\mathrm{NO}_{3}^{-} \\
\left(\mathrm{mg} \cdot \mathrm{L}^{-1}\right)\end{array}$ & $\begin{array}{l}0.00-0.00 \\
0.00 \pm 0.00\end{array}$ & $\begin{array}{l}0.00-0.01 \\
0.01 \pm 0.00\end{array}$ & $\begin{array}{l}0.00-0.00 \\
0.00 \pm 0.00\end{array}$ & $\begin{array}{l}0.00-0.00 \\
0.00 \pm 0.00\end{array}$ & $\begin{array}{l}0.00-0.00 \\
0.00 \pm 0.00\end{array}$ & $\begin{array}{l}0.00-0.00 \\
0.00 \pm 0.00\end{array}$ \\
\hline$\underset{\left(\mathrm{mgg}^{\left.-\mathrm{L}^{-1}\right)}\right.}{\mathrm{P}_{\text {total }}}$ & $\begin{array}{l}0.26-2.39 \\
1.04 \pm 0.85\end{array}$ & $\begin{array}{l}0.36-4.63 \\
2.51 \pm 1.53\end{array}$ & $\begin{array}{l}1.10-4.59 \\
2.29 \pm 1.46\end{array}$ & $\begin{array}{l}1.40-4.34 \\
2.56 \pm 1.15\end{array}$ & $\begin{array}{l}0.98-4.59 \\
2.68 \pm 1.32\end{array}$ & $\begin{array}{l}1.23-4.63 \\
2.6 \pm 1.37\end{array}$ \\
\hline $\begin{array}{c}\mathrm{Cd} \\
\left(\mathrm{mg} \cdot \mathrm{L}^{-1}\right)\end{array}$ & $\begin{array}{l}0.12-0.20 \\
0.16 \pm 0.03\end{array}$ & $\begin{array}{l}0.04-0.43 \\
0.12 \pm 0.17\end{array}$ & $\begin{array}{l}0.08-0.20 \\
0.13 \pm 0.05\end{array}$ & $\begin{array}{l}0.06-0.24 \\
0.13 \pm 0.08\end{array}$ & $\begin{array}{l}0.01-0.21 \\
0.09 \pm 0.07\end{array}$ & $\begin{array}{l}0.01-0.06 \\
0.03 \pm 0.03\end{array}$ \\
\hline $\begin{array}{c}\mathrm{Cr} \\
\left(\mathrm{mg} \cdot \mathrm{L}^{-1}\right)\end{array}$ & $\begin{array}{l}0.00-1.76 \\
0.69 \pm 0.94\end{array}$ & $\begin{array}{l}0.00-1.78 \\
0.74 \pm 0.87\end{array}$ & $\begin{array}{l}0.00-1.72 \\
0.72 \pm 0.84\end{array}$ & $\begin{array}{l}0.00-2.20 \\
0.93 \pm 1.10\end{array}$ & $\begin{array}{l}0.00-2.20 \\
0.86 \pm 1.01\end{array}$ & $\begin{array}{l}0.00-2.20 \\
0.93 \pm 1.02\end{array}$ \\
\hline $\begin{array}{c}\mathrm{Cu} \\
\left(\mathrm{mg} \cdot \mathrm{L}^{-1}\right)\end{array}$ & $\begin{array}{l}0.01-0.22 \\
0.07 \pm 0.08\end{array}$ & $\begin{array}{l}0.04-0.22 \\
0.08 \pm 0.08\end{array}$ & $\begin{array}{l}0.01-0.14 \\
0.08 \pm 0.05\end{array}$ & $\begin{array}{l}0.01-0.07 \\
0.04 \pm 0.02\end{array}$ & $\begin{array}{l}0.01-0.07 \\
0.05 \pm 0.02\end{array}$ & $\begin{array}{l}0.01-0.04 \\
0.02 \pm 0.02\end{array}$ \\
\hline $\begin{array}{c}\mathrm{Pb} \\
\left(\mathrm{mg} \cdot \mathrm{L}^{-1}\right)\end{array}$ & $\begin{array}{l}0.00-6.55 \\
1.98 \pm 2.94\end{array}$ & $\begin{array}{l}0.00-2.92 \\
0.76 \pm 1.25\end{array}$ & $\begin{array}{l}0.00-5.20 \\
1.52 \pm 2.27\end{array}$ & $\begin{array}{l}0.00-2.60 \\
0.74 \pm 1.10\end{array}$ & $\begin{array}{l}0.00-1.59 \\
0.63 \pm 0.79\end{array}$ & $\begin{array}{l}0.00-1.50 \\
0.51 \pm 0.67\end{array}$ \\
\hline $\begin{array}{c}\mathrm{Zn} \\
\left(\mathrm{mg} \cdot \mathrm{L}^{-1}\right)\end{array}$ & $\begin{array}{l}0.21-5.01 \\
1.93 \pm 2.32\end{array}$ & $\begin{array}{l}0.58-2.85 \\
1.60 \pm 1.10\end{array}$ & $\begin{array}{l}0.63-4.20 \\
1.45 \pm 1.54\end{array}$ & $\begin{array}{l}0.39-2.10 \\
0.84 \pm 0.72\end{array}$ & $\begin{array}{l}0.33-1.20 \\
0.69 \pm 0.33\end{array}$ & $\begin{array}{l}0.29-1.60 \\
0.77 \pm 0.59\end{array}$ \\
\hline
\end{tabular}

Minimum-maximum; Mean \pm standard deviation. 
identification of the collection points affected. This caused the need to consider diffuse pollutant loads for that month in the mathematical modeling of self-purification.

With respect to the water quality results for class 2 watercourses, in which the Uberabinha River is classified, discrepancies were found with the limits defined in CONAMA (National Environmental Council) Resolutions 357/2005 (BRASIL, 2005) and 430/11 (BRASIL, 2011) and COPAM (State Environmental Policy Council) Normative Deliberation 01/2008 (BRASIL, 2008), specifically for the parameters DO, BOD, $\mathrm{P}_{\text {total }}$ and the metals cadmium, chromium, lead and zinc. Regarding copper, it was not possible to compare the observed values with the regulatory limits since the latter limits refer to the maximum concentration of dissolved copper and the analyses in this study measured total copper. To clarify, the limits defined in the resolutions for class 2 rivers are: minimum of $5.0 \mathrm{mg} . \mathrm{L}^{-1}$ for $\mathrm{DO}$, maximum of $5.0 \mathrm{mg} . \mathrm{L}^{-1}$ for BOD, maximum of $0.1 \mathrm{mg} . \mathrm{L}^{-1}$ for $\mathrm{P}_{\text {total }}$, maximum of $0.001 \mathrm{mg} \cdot \mathrm{L}^{-1}$ for cadmium, maximum of $0.05 \mathrm{mg} . \mathrm{L}^{-1}$ for chromium, maximum of $0.01 \mathrm{mg} \cdot \mathrm{L}^{-1}$ for lead and maximum of $0.18 \mathrm{mg} \cdot \mathrm{L}^{-1}$ for zinc.

At point 1, located upstream from the Uberabinha WTS, the surface water quality was degraded by clandestine discharge of sewage into local streams flowing into the Uberabinha River. The same finding was reported by Rosolen et al. (2009).

The assessment of metals is necessary because at high concentrations they can cause negative effects on the environment and living things.

Cadmium, used to galvanize steel and as an anticorrosion agent, is released in watercourses by disintegration of rocks, erosion or fluvial transport. The frequent ingestion of this metal in seafood such as oysters, scallops, mollusks and crustaceans can alter the metabolism of calcium in the liver and kidneys of mammals, weakening the bones and promoting osteoporosis (Harte et al., 1991).

Lead, found in batteries, rain gutters, paints, ceramics, roof tiles and X-ray radiation protectors, has low solubility in water and is mainly transported by air, so this is the main route by which plants absorb this toxic substance (Parsons \& Dixon, 2014). Spices, cereals and canned foods generally have the highest levels of lead (Intawongse \& Dean, 2006). One-off exposure to high concentrations can cause gastrointestinal disorders, renal and hepatic lesions, hypertension and neurological effects. Prolonged exposure to lower levels can cause anemia, headaches, irritability, lethargy, convulsions, muscular weakness, ataxia, tremors, paralysis and cancer (Harte et al., 1991).

Copper, from mining, metal casting, manufacture of electrical wiring, metal alloys and runoff from pesticides, is usually found in natural aquatic systems in small concentrations and generally in cupric form $\left(\mathrm{Cu}^{+2}\right)$, linked to carbonates, cyanides, amino acids and other chemical substances. However, in sediments it is deposited in the form of hydroxides, phosphates and sulfates (Shotyk \& Le Rouxy, 2005). Copper can penetrate biological tissues by different pathways, such as oral, inhalation or cutaneous absorption. In humans, the ingestion of salts of this metal can cause gastrointestinal and renal pathologies, with varied symptoms, ranging from deep abdominal pains, vomiting, hepatic necrosis, hypertension, tachycardia, convulsion and even death.

Chromium is released into the environment by producers of dyes, lacquers and paints, leather tanneries and steel alloy makers. It is not found in nature in its elementary form, but rather is combined with other minerals. Chromium is not quickly absorbed, but absorption of $\mathrm{Cr}$ (VI) is faster (Sá Ferreira, 2001). Its toxicity is usually manifested by renal problems in humans (Lamson \& Plaza, 2002), mutagenic effects (Qian, 2004) and germination inhibition of seeds, stunted growth of plants (Yogeetha et al., 2004) and peroxidation of lipids associated with the formation of reactive oxygen species in plants.

Zinc is an essential metal found in some foods, soils and volcanic rocks, as well as in drinking water in the form of salts or organic complexes. The daily zinc requirement for human adults is 15 to $20 \mathrm{mg}$, and the main sources of the element are meat, fish, poultry, dairy products, cereals, grains, vegetables and fruits. This metal also has protective action against the toxic effects of cadmium and lead, but the exaggerated ingestion of foods containing zinc can cause colic, nausea, vomiting, diarrhea and fever.

\subsection{Estimated and calibrated state variables}

Table 3 reports the calibrated and estimated values from the literature, for each stretch of the river, of the coefficients of the biochemical reactions, diffuse load and resurgence, besides the benthic DO demand measured in the laboratory, considered in the water quality modeling of the Uberabinha River.

According to Table 3, the values estimated by the literature for the coefficients $k_{d} k_{d} k_{3} K_{o a,} K_{n n}, K_{a n}$ and $K_{P}$ 


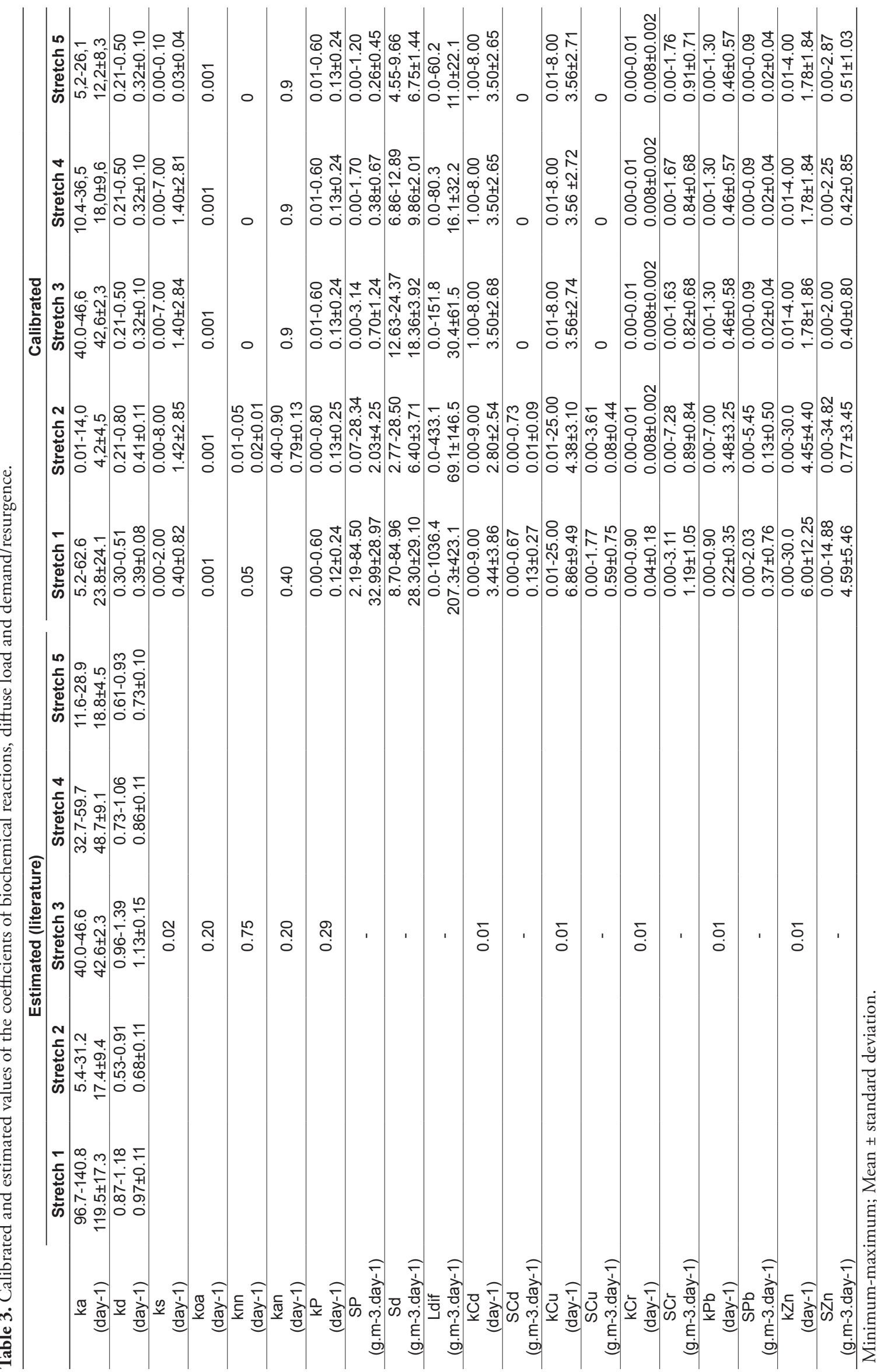


follow the recommendations of Chapra (2003) and Von Sperling (2007). Similar values were used by Ferreira (2014) and Salla et al. (2015). With the exception of $k_{a}$ and $k_{d}$, which were obtained from the hydraulic relations, all the other estimated coefficients were held constant in the period from June to October 2015.

The values estimated for $k_{C r}, k_{C d} k_{C u}, k_{P b}$ and $k_{z n}$ were assumed to be fixed and equal to 0.01 day ${ }^{1}$, according to Paredes-Arquiola et al. (2010). The estimated resurgence loads of metals $\left(S_{C r}, S_{C d} S_{C u}, S_{P b}\right.$ and $\left.S_{z n}\right)$ and phosphorus $\left(S_{P}\right)$ and benthic DO demand $\left(S_{d}\right)$ were considered nil based on the lack of data in the literature. The estimated diffuse load $\left(L_{\text {diffus }}\right)$ was disregarded because the study was carried out in the dry season.

The comparison between the calibrated state variables with those found in the literature brings some important information about how adequate the water quality modeling is in lotic environments based on state variables obtained from the literature. The discrepancies found between the estimated and calibrated values are associated with the low capacity for dilution of pollutants in the dry season and the high pollutant load discharged by the Uberabinha WTS.

Regarding the coefficient of natural reaeration $\left(k_{a}\right)$, the equations in the literature overestimate its value. Using stretch 2 as an example, $k_{a}$ from the literature is on average four times the calibrated value.

Likewise, the equations in the literature overestimate the coefficient of decomposition of carbonaceous organic matter $\left(k_{d}\right)$. Again employing stretch 2 as an example, $k_{d}$ from the literature is on average about 1.6 times the calibrated value. This fact shows the need to calibrate $k_{a}$ and $k_{d}$ based on water quality date monitored along the entire course of the river studied.

In the calibration process, the coefficient of decay by sedimentation of carbonaceous organic matter in the river $(k)$ was higher than the value of 0.02 day $^{-1}$ recommended by the literature (average of 0.40 day $^{-1}$ in June 2015, 1.42 day $^{-1}$ in July 2015, 1.40 day $^{-1}$ in August 2015, 1.40 day $^{-1}$ in September 2015 and 0.03 day $^{-1}$ in October 2015, as shown in Table 3).

For the ammonification process, the estimated and calibrated values in the dry season of the coefficient of conversion of organic nitrogen into ammonia $\left(K_{o a}\right)$ were not close $\left(0.20\right.$ day $^{-1}$ estimated and 0.001 day $^{-1}$ calibrated). Regarding nitrification, fixed values of $k_{a n}$ equal to 0.20 day $^{-1}$ and $k_{n n}$ equal to 0.75 day $^{-1}$ were used in the simulations based on coefficients from the literature. The calibrated coefficients $k_{a n}$ were between 0.40 and 0.90 day $^{-1}$ and $k_{n n}$ were between 0.00 and 0.05 day $^{-1}$ (Table 3). In this study, the low calibrated values of $k_{n n}$ are directly related to the low concentrations of nitrate in the water.

Regarding the total phosphorus parameter, the average value of the calibrated coefficient of decay $\left(k_{p}\right)$ was lower than that estimated in the literature in all the stretches $\left(0.29\right.$ day $^{-1}$ estimated and 0.13 day $^{-1}$ calibrated). The calibrated values of release of $\mathrm{P}_{\text {inorg }}$ by the bottom sediment $\left(S_{P}\right)$ were on average $32.99 \mathrm{~g} \cdot \mathrm{m}^{-3}$.day ${ }^{-1}$ in stretch $1,2,03 \mathrm{~g} \cdot \mathrm{m}^{-3} \cdot$ day $^{-1}$ in stretch 2, 0.70 g.m $\mathrm{m}^{-3}$.day ${ }^{-1}$ in stretch $3,0.38 \mathrm{~g} . \mathrm{m}^{-3}$. day $^{-1}$ in stretch 4 and 0.26 g.m. ${ }^{-3}$.day ${ }^{-1}$ in stretch 5. The tendency for these values do decline in stretches 3, 4 and 5 is related to the capacity for sedimentation of inorganic phosphorus in stretch 2, specifically near the reservoir of the Martins PP.

The calibrated diffuse BOD load $\left(L_{\text {diffus }}\right)$ was only considered in October de 2015, the rainiest month in the period studied. This metric represents the diffuse surface entry of carbonaceous organic matter along the river course, equal to 207.3, 69.1, 30.4, 16.1 and 11.0 g.m $\mathrm{m}^{-3}$.day ${ }^{-1}$, respectively, in stretches $1,2,3,4$ and 5 . The high values in stretches 1 and 2 are directly related to the land use and occupation in the region: urbanization in stretch 1 and use of fertilizers and pesticides on various crops grown in the experimental farm of Uberlândia Federal University in stretch 2 .

The benthic DO demand $\left(S_{d}\right)$ values measured in the laboratory ranged from 2.0 to $18.5 \mathrm{~g} . \mathrm{m}^{-2}$. day $^{-1}$ in stretch $1,2.0$ to $2.8 \mathrm{~g} . \mathrm{m}^{-2}$.day ${ }^{-1}$ in stretch 2 and 2.4 to $2.8 \mathrm{~g}^{-\mathrm{m}^{-2}}$.day ${ }^{-1}$ in stretches 3,4 and 5 . The literature in this respect reports values close to these in watercourses with similar morphological and water quality characteristics. For example, Thomann and Mueller (1987) reported ranges from 1.0 to $2.0 \mathrm{~g} \cdot \mathrm{m}^{-2}$.day ${ }^{-1}$ and Penteado (2009) observed 0.5 to 7.0 g. $\mathrm{m}^{-2}$.day ${ }^{-1}$. For comparison, in watercourses with good quality because they do not receive considerable sewage loads, the reported benthic DO demand values are lower, on the order of 0.10 to $1.4 \mathrm{~g} . \mathrm{m}^{-2}$.day ${ }^{-1}$ (Edeberg \& Hofsten, 1973; Salla et al., 2014b).

Salla et al. (2014b), in analyzing the water quality of the same river, in a segment approximately $48 \mathrm{~km}$ long of the upper, middle and lower course, in the period from October 2006 to September 2011, obtained the following calibrated values of coefficients: $k_{a}\left(0.08\right.$ day $\left.^{-1}\right), k_{d}\left(0.05-0.06\right.$ day $\left.^{-1}\right)$, 
$k_{a n}\left(0.01-0.2 \mathrm{day}^{-1}\right), K_{o a}\left(0.2-0.4 \mathrm{day}^{-1}\right)$ and $K_{P}\left(0.01\right.$ day $\left.^{-1}\right)$. In comparison with Salla et al. (2014a), we believe the discrepancies of the coefficients are related to the source of the water quality data. While Salla et al (2014a) used water quality data from monitoring by a company contracted by the municipal water and sewer department and by the Institute for Management of Mineral Waters, we used our own data obtained in the field.

The main scientific contributions of this study were the calibration of the coefficient of decay and quantification of the release from bottom sediment of the metals cadmium, copper, chromium, lead and zinc in a watercourse receiving discharge from a large waste treatment station (capacity to treat effluent from a population of up to 730,000 people). The literature is lacking in studies of the decay kinetics and resurgence from the bottom of metals in watercourses with the same characteristics as that studied here. On the other hand, the literature contains plentiful information on physical and biochemical interferences in the seasonal behavior of heavy metals based on monitoring at fixed points (Superville et al., 2015; Pourabadehei \& Mulligan, 2016; Zhang et al., 2016; Mohammad Ali et al., 2016; Bastami et al., 2012; Fu et al., 2014; Islam et al., 2015; Saleem et al., 2015; among others).

For stretches 1 to 5 , the average coefficient of decay $\left(k_{\text {metal }}\right)$ values were between 2.80 and 3.50 day $^{-1}$ for cadmium, 3.56 and $6.86 \mathrm{day}^{-1}$ for copper, 0.008 and $0.04 \mathrm{day}^{-1}$ for chromium, 0.22 and 3.48 day $^{-1}$ for lead and 1.78 and 6.00 day $^{-1}$ for zinc. In turn, the values for release of metals from the bottom sediment $\left(S_{\text {metal }}\right)$ for stretches 1 to 5 were: 0 to $0.13 \mathrm{~g} \cdot \mathrm{m}^{-3}$. day $^{-1}$ for cadmium; 0 to $0.59 \mathrm{~g} \cdot \mathrm{m}^{-3}$. day ${ }^{-1}$ for copper; 0.82 to 1.19 g. $\mathrm{m}^{-3}$.day ${ }^{-1}$ for chromium; 0.02 to $0.37 \mathrm{~g} \cdot \mathrm{m}^{-3} \cdot \mathrm{day}^{-1}$ for lead; and 0.40 to $4.59 \mathrm{~g} \cdot \mathrm{m}^{-3}$.day ${ }^{-1}$ for zinc. Since the study was carried out in the dry season, the monthly variations of $k_{\text {metal }}$ and $S_{\text {metal }}$ do not show a logical tendency for growth or decline in function of the month analyzed. The order of size of the coefficient of decay for metals is usually high, with the exception of chromium, which has low adsorption capacity (Sá Ferreira, 2001).

We also evaluated the influence of longitudinal declivity on the estimated and calibrated values of the state variables. Regarding the coefficient of natural reaeration $\left(k_{a}\right)$ from the literature, a direct relation exists between higher $k_{a}$ values and greater declivities in stretches 1, 3 and 4. This pattern held for the calibrated values.

With respect to the coefficient of decomposition of carbonaceous organic matter $\left(k_{d}\right)$ from the literature, a direct relation exists between higher values of $k_{d}$ and greater declivities in stretches 1, 3 and 4. For the calibrated values of $k_{d}$, this relation only held in October 2015 in stretches 1 and 2 . This indicates that the surface diffuse contribution of organic matter $\left(L_{\text {diffus }}\right)$ in stretches 1 and 2, associated with the influence of the reservoir at Martins PP (which considerably increases the accumulation of bottom sediment), prevails over the effects of longitudinal declivity.

According to Table 3, the coefficients from the literature and calibrated ones used for ammonification and nitrification $\left(K_{o a}, k_{a n}\right.$ and $\left.k_{n n}\right)$ were not influenced significantly by the change in longitudinal declivity in the five stretches. The same situation was observed for decay of total phosphorus $\left(k_{p}\right)$, decay of cadmium and chromium $\left(K_{C d}\right.$ and $K_{C}$ ) and release of cadmium and chromium by the bottom sediment $\left(S_{C d}\right.$ and $\left.S_{C}\right)$. The situation was opposite for release of $\mathrm{P}_{\text {inorg }}$ by the bottom sediment $\left(S_{p}\right)$, for decay of copper, lead and zinc $\left(k_{C u}, k_{P b}\right.$ and $\left.k_{Z n}\right)$ and release of copper, lead and zinc by the bottom sediment $\left(S_{C u}, S_{P b}\right.$ and $\left.S_{Z n}\right)$.

\subsection{Simulation profiles}

As shown by Figure 4, the time series simulated by the calibration process and the data measured at points 3, 4, 5 and 6 presented good fits according to the Nash-Sutcliffe coefficient for the parameters DO (coefficient of 0.91 to 0.99 ), BOD (0.96 to 0.99$)$, ammonia (0.83 to 0.98$)$, total phosphorus ( 0.90 to 1,00$)$, cadmium ( 0.83 to 0.91 ), lead (0.84 to 0.99$)$, copper ( 0.70 to 0.99$)$, zinc (0.81 to 0.93 ) and chromium (0.97 to 0.98$)$. The exception was the nitrate parameter, where the time series were above the values measured in all months studied, but with the same monthly variation tendency.

Figure 5 compares the longitudinal profiles of the simulated parameters based on the calibrated state variables with the simulated profiles based on the state variables obtained from the literature, along with the water quality data monitored at points 3 to 6 . In this figure, comparison of the longitudinal profiles of the simulations based on the calibrated values with the measured water quality data shows good adjustments between the simulated and measured data for all the parameters analyzed. The comparison of the water quality model using 

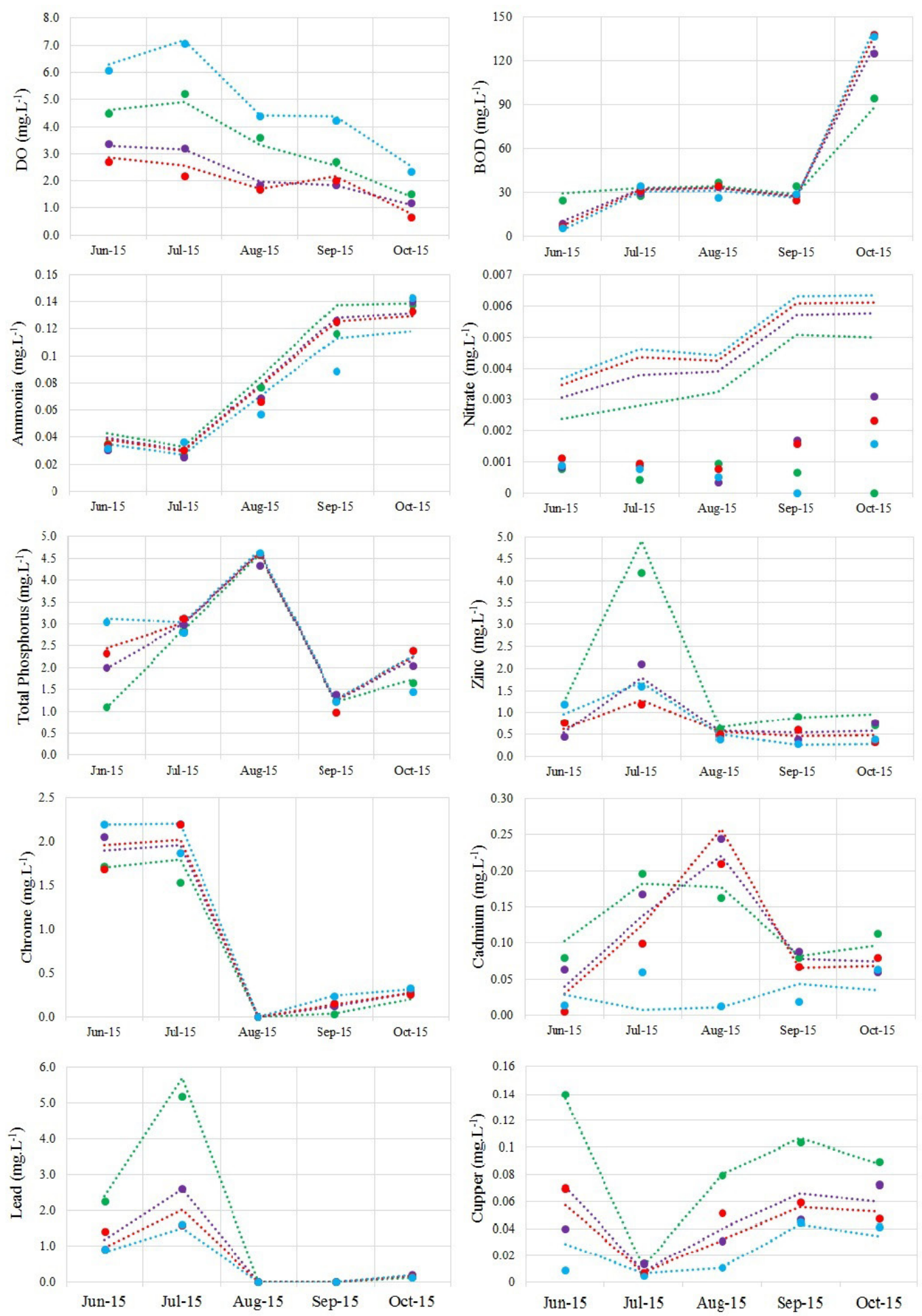

Figure 4. Fit between the simulated time series based on the calibration process and data measured at points 3, 4, 5 and 6 .

calibrated data with the model using variables obtained from the literature reveals inconsistencies for the parameters DO, $\mathrm{P}_{\text {total }}$, ammonia, nitrate and all the heavy metals.

The sharp discrepancies of the longitudinal profiles for DO are related to the coefficient of natural reaeration $\left(k_{a}\right)$, which is overestimated by the equations from the literature, as mentioned previously.

With respect to $\mathrm{BOD}$, although the equations from the literature overestimate the value of the coefficient of decomposition of carbonaceous 

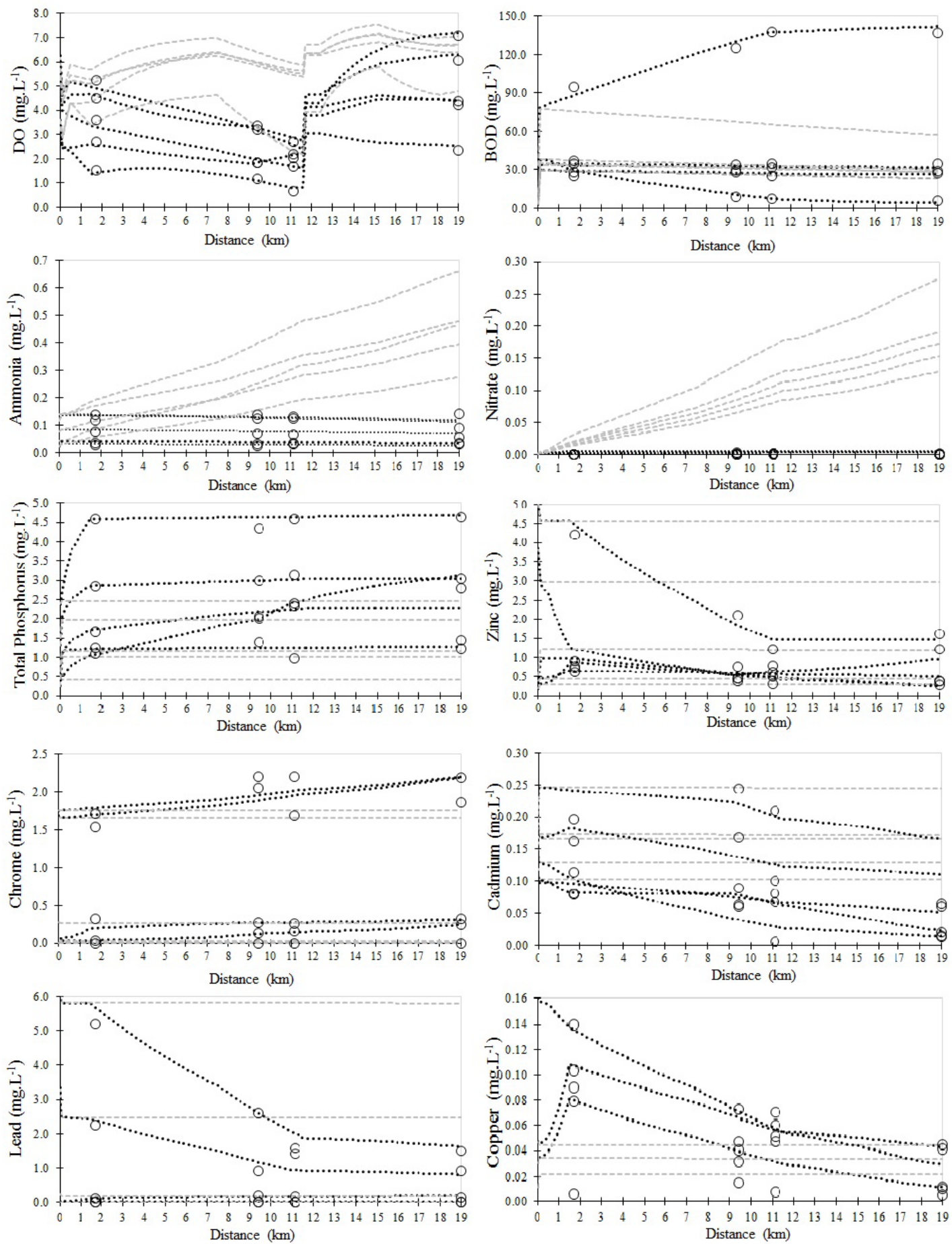

Figure 5. Longitudinal profiles of the simulated water quality parameters and water quality data monitored at points 3 to 6 .

organic matter in the river $\left(k_{d}\right)$ by an average of approximately 1.6 times the calibrated value, Figure 5 shows a certain proximity between the longitudinal profiles for this parameter. The only discrepancy in the BOD profile was in October 2015, due to the diffuse load $\left(L_{d i f f}\right)$ considered in stretches 1 and 2 .
The explanation for the discrepancy in the profiles of the total phosphorus parameter (see Figure 5) is the omission of the bottom resurgence of inorganic phosphorus in the simulations based on values from the literature. Even though the coefficient of decay of total phosphorus (which encompasses the conversion of organic into inorganic phosphorus 
and sedimentation of inorganic phosphorus) in the calibration was about double the value from the literature, the bottom resurgence of inorganic phosphorus prevailed in the model for total phosphorus, mainly in stretch 1 .

The accentuated discrepancies between the profiles of the ammonia and nitrate parameters (see Figure 5) are related to the high values of the coefficients from the literature involving ammonification $\left(K_{o a}\right.$ equal to $\left.0.20 \mathrm{day}^{-1}\right)$. To support this affirmation, Table 3 shows that the sum of the coefficients involved in nitrification $\left(K_{a n}\right.$ and $\left.K_{n n}\right)$ from literature data and the calibration are close in all five stretches.

In the simulations of the heavy metals, in the calibration process the resurgence load tended to prevail over the decay of these metals due to the high longitudinal declivity of stretch 1 . Even though the data were collected in the dry season, the high longitudinal declivity in this stretch caused resuspension of the metal absorbed in inorganic matter. In contrast, in stretches 2, 3, 4 and 5 the decay of copper, zinc, lead and cadmium prevailed over the resurgence from the bottom.

With respect to the metals chromium and lead in June and July 2015, the low concentrations found in the river allowed good proximity between the simulated profiles, irrespective of the values of the coefficient of decay of metals and the resurgence load considered. In turn, in August, September and October 2015, the resurgence loads tended to prevail over the decay of chromium in stretches 2, 3, 4 and 5 .

The discrepancies in the profiles of the metals can be explained by the disregard in the simulations from literature values of the bottom resurgence of metals and the consideration of a single coefficient of decay for all the metals, equal to $0.01 \mathrm{day}^{-1}$.

The discrepancies discussed above add further evidence of the need for constant monitoring of water quality for adequate calibration of mathematical models of self-purification.

\subsection{Sensitivity analysis}

We also analyzed the sensitivity of the behavior of the water quality parameters based on fluctuations of $+10 \%$ and $-10 \%$ in the calibrated values of the

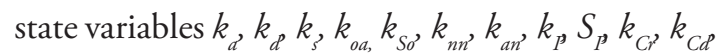
$k_{C u^{\prime}} k_{P b^{\prime}}, k_{z n^{\prime}} S_{C{ }^{\prime}} S_{C d^{\prime}} S_{C u^{\prime}}, S_{P b^{\prime}} S_{z n}$ and $S_{d^{\circ}}$

The highest average percentages of variation of the DO occurred with the oscillations of $k_{d}, k_{d}$ and $S_{d}$, which were, respectively, $5.5 \%, 2.0 \%$ and $1.8 \%$ in June, $2.7 \%, 1.9 \%$ and $1.0 \%$ in July,
5.3\%, 2.8\% and 4.5\% in August, 7.8\%, 3.4\% and $2.6 \%$ in September, and $29.7 \%, 16.7 \%$ and $3.7 \%$ in October. These results show that in October, when rainfall of $32 \mathrm{~mm}$ occurred on the collection day, the increase in flow of the river considerably increased the sensitivity in the fluctuation of the coefficients $k_{a}$ and $k_{d}$. In the dry season in general, oscillations of $k_{d}, k_{d} k_{n n}, k_{a n}$ and $S_{d}$ caused little variation in the concentration of DO.

With respect to the BOD parameter, the highest average variation $(21.4 \%)$ occurred with the fluctuation of $k$ in June. For the other months, no variation was observed in function of the disregard of $k_{s}$. The fluctuation of $k_{d}$ showed a very small variation of $\mathrm{BOD}$, with maximum values of $1.7 \%$ in June, $0.8 \%$ in July, $0.9 \%$ in August, $1.1 \%$ in September and $1.0 \%$ in October.

Although to a lesser extent, the highest variation percentages of the ammonia and nitrate parameters occurred in function of the oscillations of the coefficients $k_{a n}$ and $k_{n n}$, respectively. The fluctuations of $k_{a n}$ and $k_{n n}$ were $2.3 \%$ and $5.5 \%$ in June, $1.8 \%$ and 6,2\% in July, $1.8 \%$ and $4.4 \%$ in August, $1.9 \%$ and $3.0 \%$ in September, and $1.5 \%$ and $3.6 \%$ in October.

Only the fluctuation of $S_{P}$ affected the variation of total phosphorus, with figures of $8.6 \%$ variation in June, $3.5 \%$ in July, $4.7 \%$ in August, $0.8 \%$ in September, and $5.5 \%$ in October. Similar results for the parameters DO, BOD, total phosphorus, ammonia and nitrate were obtained by Salla et al. (2014a, b).

The oscillations of $k_{\text {metal }}$ and $S_{\text {metal }}$ did not follow the same pattern as the variations of cadmium, chromium, copper, lead and zinc. Only the fluctuation of $k_{\text {metal }}$ caused variations of cadmium, equal to $22.7 \%$ in June, $4.9 \%$ in July, $3.5 \%$ in August, $12.9 \%$ in September, and 5.9\% in October. In counterpart, only the fluctuation of $S_{\text {metal }}$ varied for chromium, equal to $2.5 \%$ in June, $2.1 \%$ in July, $22.2 \%$ in September, and $15.5 \%$ in October.

For copper, the oscillations of $k_{\text {metal }}$ (in all months) and $S_{\text {metal }}$ (only in August and September) caused variations in the concentration of this metal. The fluctuation of $k_{\text {metal }}$ caused variations of copper of $16.5 \%$ in June, $11.7 \%$ in July, $18.5 \%$ in August, $8.9 \%$ in September, and $10.1 \%$ in October. Also, the fluctuation of $S_{\text {metal }}$ varied for copper by $8.8 \%$ in August and $9.1 \%$ in September.

Similar to the results for copper, the oscillations of $k_{\text {metal }}$ and $S_{\text {metal }}$ caused impacts on the concentration of lead in dispersed form. The fluctuation of $k_{\text {metal }}$ varied for this metal by $11.4 \%$ in June and $13.1 \%$ 
in July, while the fluctuation of $S_{\text {metal }}$ varied only in October, by $19.5 \%$.

For zinc, the oscillations of $k_{\text {metal }}$ (in all months) and $S_{\text {metal }}$ (in June, August and September) caused variations. The fluctuation of $k_{\text {metal }}$ caused variations of $20.3 \%$ in June, $12.0 \%$ in July, $2.3 \%$ in August, $11.2 \%$ in September, and $11.8 \%$ in October. Finally, the fluctuation of $S_{\text {metal }}$ varied for zinc by $5.9 \%$ in June, $3.7 \%$ in August and $10.8 \%$ in September. The months without sensitivity can be explained by the low concentration of this metal.

\section{Conclusions}

The mathematical modeling of self-purification of the Uberabinha River, in the municipality of Uberlândia, Minas Gerais, impacted by the release of effluents from the Uberabinha waste treatment station, was successful. Although not the main focus of this study, it is important to stress that in the period studied the values of the parameters $\mathrm{DO}, \mathrm{BOD}, \mathrm{P}_{\text {total }}$ and the levels of the heavy metals cadmium, chromium, lead and zinc were above the limits defined by CONAMA Resolutions 357/2005 (BRASIL, 2005) and 430/11 (BRASIL, 2011) and COPAM Normative Deliberation 01/2008 (BRASIL, 2008) for class 2 watercourses.

The calibration process allowed good fits between the simulated and measured data for all the parameters analyzed. In counterpart, the comparison of the water quality model based on the calibrated state variables and those obtained in the literature revealed inconsistencies for the parameters DO, $\mathrm{P}_{\text {total }}$, ammonia, nitrate and all the heavy metals.

The sensitivity analysis showed that the most important state variables were $k_{d} k_{d}$ and $S_{d}$ for $\mathrm{DO}$, $k_{s}$ for BOD, $S_{P}$ for total phosphorus, $k_{n n}$ for nitrate, $k_{\text {metal }}$ and $S_{\text {metal }}$ for heavy metals. No state variables were important to variation of ammonia.

In general, the results reinforce the importance of calibration in mathematical modeling of self-purification, principally in lotic environments that receive high pollution loads in the dry season.

\section{Acknowledgements}

We thank the Office to Improve University Personnel (CAPES) of the Ministry of Education for the master's scholarship granted to the first author and postdoctoral scholarship granted to the last author. We also thank the Minas Gerais State Research Support Foundation (FAPEMIG, process CRA APQ-01024-14) for financial support of this study.

\section{References}

ASSOCIAÇÃO BRASILEIRA DE NORMAS TÉCNICAS - ABNT. NBR 9649:1986. Projeto de redes coletoras de esgoto sanitário [online]. Rio de Janeiro: ABNT, 1986, 7 p. [viewed 10 May 2015]. Avaliable from: www.abnt.org.br

ASSOCIAÇÃO BRASILEIRA DE NORMAS TÉCNICAS - ABNT. NBR 9898:1987. Preservação e técnicas de amostragem de efluentes líquidos e corpos receptores [online]. Rio de Janeiro: ABNT, 1987, 22 p. [viewed 10 May 2015]. Avaliable from: www. abnt.org.br

ASSOCIAÇÃO BRASILEIRA DE NORMAS TÉCNICAS - ABNT. NBR 14486:2000. Buried sewerage systems - Design of pipe lines with poly (vinyl chloride) (PVC) pipes [online]. Rio de Janeiro: ABNT, 2000, 19 p. [viewed 10 May 2015]. Avaliable from: <www.abnt.org.br

BAIRD, C. Environmental chemistry. Porto Alegre: Freeman, 2002.

BASTAMI, K.D., BAGHERI, H., HAGHPARAST, S., SOLTANI, F., HAMZEHPOOR, A. and BASTAMI, M.D. Geochemical and geo-statistical assessment of selected heavy metals in the surface sediments of the Gorgan Bay, Iran. Marine Pollution Bulletin, 2012, 64(12), 2877-2884. PMid:22995783. http://dx.doi.org/10.1016/j.marpolbul.2012.08.015.

BRASIL. Ministério do Meio Ambiente. Conselho Nacional do Meio Ambiente - CONAMA. Resoluçâo no 357, de 17 de março de 2005. Dispóe sobre a classificação dos corpos de água e diretrizes ambientais para o seu enquadramento, bem como estabelece as condiçóes e padróes de lançamento de efluentes, e dá outras providências. Diário Oficial da Uniāo (da) República Federativa do Brasil, Poder Executivo, Brasília, DF, 18 mar. 2005. pp. 58-63.

BRASIL. Conselho Estadual de Política Ambiental - COPAM. Deliberação Normativa Conjunta COPAM/CERH-MG no 01, de 05 de maio de 2008. Dispóe sobre a classificação dos corpos de água e diretrizes ambientais para o seu enquadramento, bem como estabelece as condiçóes e padrôes de lançamento de efluentes, e dá outras providências. Diário do Executivo - "Minas Gerais", Belo Horizonte, MG, 15 maio 2008.

BRASIL. Ministério do Meio Ambiente. Conselho Nacional do Meio Ambiente - CONAMA. Resolução $n^{\circ} 430$, de 13 de maio de 2011. Dispóe sobre as condiçóes e padróes de lançamento de efluentes, complementa e altera a Resoluçáo no 357, de 17 de março de 2005, do Conselho Nacional do Meio Ambiente-CONAMA. Diário Oficial da União (da) República Federativa do Brasil, Poder Executivo, Brasília, DF, 16 maio 2011.

BUENO, L.F., GALBIATTI, J.A. and BORGES, M.J. Management of water quality in Ouro Verde Garden, 
Conchal - SP, Brazil. Engenharia Agrícola, 2005, 25(3), 742-748. http://dx.doi.org/10.1590/S010069162005000300020

CHAPRA, S.C. Engineering water quality models and TDMLs. Journal of Water Resources Planning and Management, 2003, 129(4), 247-256. http://dx.doi. org/10.1061/(ASCE)0733-9496(2003)129:4(247).

CHAPRA, S.C. Surface water-quality modeling. Long Grove: McGraw-Hill, 1997. Higher Education.

CHOW, V.T. Open-channel hydraulics. Chicago: The Blackburn Press, 2009.

EDEBERG, N. and HOFSTEN, B.V. Oxygen uptake of bottom sediments studies and in laboratory. Water Research, 1973, 7(9), 1285-1294. http://dx.doi. org/10.1016/0043-1354(73)90005-5.

FERREIRA, A. M. Capacidade de autodepuração no médio e baixo curso do Rio Uberaba, UPGRH-GD8. Uberlândia: Universidade Federal de Uberlândia, 2014. 134 p. Dissertação de Mestrado em Engenharia Civil.

FU, J., ZHAO, C., LUO, Y., LIU, C., KYZAS, G.Z., LUO, Y., ZHAO, D., AN, S. and ZHU, H. AN, S. and $\mathrm{ZHU}, \mathrm{H}$. Heavy metals in surface sediments of the Jialu river, China: their relations to environmental factors. Journal of Hazardous Materials, 2014, 270(1), 102-109. PMid:24561322.

HARTE, J., HOLDREN, C., SCHENEIDER, R. and SHIRLEY, C. Toxics $A$ to $Z$ : A guide to everyday pollution hazards. Oakland: University of California Press, 1991.

INTAWONGSE, M. and DEAN, J.R. Uptake of heavy metals by vegetable plants grown on contaminated soil and their bioavailability in the human gastrointestinal tract. Food Additives and Contaminants, 2006, 23(1), 36-48. PMid:16393813. http://dx.doi.org/10.1080/02652030500387554.

ISLAM, M.S., AHMED, M.K., HABIBULLAH-ALMAMUN, M. and HOQUE, M.F. Preliminary assessment of heavy metal contamination in surface sediments from a river in Bangladesh. Environ. Earth Sciences, 2015, 73(4), 1837-1848. http://dx.doi. org/10.1007/s12665-014-3538-5.

LAMSON, D.W. and PLAZA, S.M. The safety efficacy of high-dose chromium. Alternative Medicine Review, 2002, 7(3), 218-235. PMid:12126463.

MCKNIGHT, R.F., ADIDA, M., BUDGE, K., STOCKTRON, S., GOODWIN, G.M. and GEDDES, J.R. Lithium toxicity profile: a systematic review and meta-analysis. Lancet, 2012, 379(9817), 721-728. PMid:22265699. http://dx.doi. org/10.1016/S0140-6736(11)61516-X.

MOHAMMAD ALI, M., ALI, M.L., ISLAM, M.S. and RAHMAN, M.Z. Preliminary assessment of heavy metals in water and sediment of Karnaphuli river, Bangladesh. Environmental Nanotechnology. Monitoring \& Management, 2016, 5(1), 27-32.
NATIONAL INSTITUTE FOR SPACE RESEARCH INPE. TOPODATA: banco de dados geomorfométricos do Brasil [online]. São José dos Campos: INPE, 2015 [viewed 14 Nov. 2015]. Available from: http://www. dsr.inpe.br/topodata/index.php

NATIONAL INSTITUTE OF METEOROLOGY - INMET. Estação meteorológica de observação de superficie automática [online]. [viewed 01 Jan. 2016]. Brasília: INMET, 2016. Available from: http:// www.inmet.gov.br/portal/index.php?r=estacoes/ estacoesautomaticas

PAREDES-ARQUIOLA, J., ANDREU-ÁLVAREZ, J., MARTÍN-MONERRIS, M. and SOLERA, A. Water quantity and quality models applied to the Jucar river basin, Spain. Water Resources Management, 2010, 24(11), 2759-2779. http:// dx.doi.org/10.1007/s11269-010-9578-z.

PARSONS, P. and DIXON, G. The periodic table: a field guide to the elements. London: Quercus Publishing Inc., 2014.

PENTEADO, E. D. Modelagem da qualidade da água do rio Monjolinho utilizando o modelo QUAL-2E: ênfase em matéria orgânica. São Carlos: Escola de Engenharia, Universidade de São Paulo, 2009. 81 p. Trabalho de Conclusão de Curso.

POURABADEHEI, M. and MULLIGAN, C.N. Effect of the resuspension technique on distribution of the heavy metals in sediment and suspended particulate matter. Chemosphere, 2016, 153(1), 5867. PMid:27010167. http://dx.doi.org/10.1016/j. chemosphere.2016.03.026.

QIAN, X.W. Mutagenic effects of chromium trioxide on root tip cells of Vicia faba. Journal of Zhejiang University Science, 2004, 5(12), 1570-1576. PMid:15547966. http://dx.doi.org/10.1631/ jzus.2004.1570.

ROSOLEN, V., HERPIN, U., COELHO, N.M.M., COELHO, L.M., BRITO, J.L.S., SILVA, L.A. and LIMA, S.C. Sediment quality in Uberabinha river (Uberlândia, MG) and environmental implications. Brazilian Journal of Geology, 2009, 39(1), 151-159.

SÁ FERREIRA, R. J. Determinação de metais traço em sedimentos de rios: caso da Bacia do Baixo Itajaí$A c ̧ u$. Florianópolis: Universidade Federal de Santa Catarina, 2001. 121 p. Dissertação de Mestrado Interinstitucional em Química.

SALEEM, M., IQBAL, J. and SHAH, M.H. Geochemical speciation, anthropogenic contamination, risk assessment and source identification of selected metals in fresh water sediments - A case study from Mangla lake, Pakistan. Environmental Nanotechnology, Monitoring \& Management, 2015, 4(1), 27-36.

SALLA, M.R., ARQUIOLA, J.P., ELVIRA, N.L., ALAMY FILHO, J.E., PEREIRA, C.E. and COSTA, E.S. Application of tool EVALHID for parameters calibration and flow simulation on the 
high course of the river Araguari, Minas Gerais. Revista Brasileira de Recursos Hidricos, 2015, 20(1), 276-285. http://dx.doi.org/10.21168/rbrh.v20n1. p276-285.

SALLA, M.R., PEREIRA, C.E., ALAMY FILHO, J.E., PAULA, L.M. and PINHEIRO, A.M. Selfdepuration study of Jordão river, located in Dourados river Basin. Engenharia Sanitária e Ambiental, 2013a, 18(2), 105-114. http://dx.doi.org/10.1590/S141341522013000200002.

SALLA, M.R., ARQUIOLA, J.P., SOLERA, A., ALVAREZ, J.A., PEREIRA, C.E., ALAMY FILHO, J.E. and OLIVEIRA, A.L. Decision support system for water resources in the basin river Uberabinha, Minas Gerais. Revista Brasileira de Recursos Hidricos, 2013b, 19(1), 189-204. http://dx.doi.org/10.21168/ rbrh.v19n1.p189-204.

SALLA, M.R., FERREIRA, A.M., PEREIRA, C.E. and SCHMIDT, M.A.R. Self-cleaning ability of the middle and lower courses of the Uberaba river, UPGRH-GD8. Journal of Urban and Environmental Engineering, 2014a, 8(1), 118-133. http://dx.doi. org/10.4090/juee.2014.v8n1.118133.

SALLA, M.R., PAREDES-ARQUIOLA, J., SOLERA, A., ALVAREZ, J.A., PEREIRA, C.E., ALAMY FILHO, J.E. and OLIVEIRA, A.L. Integrated modeling of water quantity and quality in the Araguari River basin, Brazi. Latin American Jornal of Aquatic Research, 2014b, 42(1), 224-244. http:// dx.doi.org/10.3856/vol42-issue1-fulltext-19.

SCHNEIDER, M. O. Bacia do Rio Uberabinha: uso agrícola do solo e meio ambiente. São Paulo: Departamento de Geografia da Faculdade de Filosofia, Letras e Ciências Humanas, Universidade de São Paulo, 1996. 157 p. Tese Doutorado em Geografia.

SHOTYK, W. and LE ROUXY, G. Biogeochemistry and cycling of lead. Metal Ions in Biological Systems, 2005, 43(1), 239-275. PMid:16370121. http://dx.doi. org/10.1201/9780824751999.ch10.

SULIS, A. and SECHI, G.M. Comparison of generic simulation models for water resource systems. Environmental Modelling \& Software, 2013,
40(1), 214-225. http://dx.doi.org/10.1016/j. envsoft.2012.09.012.

SUPERVILLE, P.J., PRYGIEL, E., MIKKELSEN, O. and BILLON, G. Dynamic behavior of trace metals in the Deûle River impacted by recurrent polluted sediment resuspensions: from diel to seasonal evolutions. The Science of the Total Environment, 2015, 507(1), 585-593. PMid:25433380. http:// dx.doi.org/10.1016/j.scitotenv.2014.11.044.

THOMANN, R.V. and MUELLER, J.A. Principles of surface water quality modeling and control. New York: Harper Collins Publishers Inc., 1987.

VON SPERLING, M. Principles of biological treatment of wastewater: study and modeling of river water quality. Belo Horizonte: Universidade Federal de Minas Gerais, 2007.

YENILMEZ, F. and AKSOY, A. Comparison of phosphorus reduction alternatives in control of nutrient concentrations in Lake Uluabat (Bursa, Turkey): Partial versus full sediment dredging. Limnologica - Ecology and Management of Inland Waters, 2013, 43(1), 1-9.

YOGEETHA, M.S., PRAKAS, S.M., RAMAKRISHNA, P. and RAMEGOWDA, V.R. Effect of $\mathrm{Cr}$ in irrigation water on germination and growth of French beans (Dolichos lablab L.). Journal Environmental Science Engineer, 2004, 46(3), 194-202.

ZHANG, X., HUANG, G.H., NIE, X. and LIN, Q. Model-based decision support system for water quality management under hybrid uncertainty. Expert Systems with Applications, 2011, 38(3), 2809-2816. http://dx.doi.org/10.1016/j.eswa.2010.08.072.

ZHANG, Z., JUYING, L., MAMAT, Z. and QINGFU, Y. Sources identification and pollution evaluation of heavy metals in the surface sediments of Bortala River, Northwest China. Ecotoxicology and Environmental Safety, 2016, 126(1), 94-101. PMid:26735186. http://dx.doi.org/10.1016/j.ecoenv.2015.12.025.

Received: 05 July 2016 Accepted: 28 November 2016 